\title{
Tracking Riverborne Sediment and Contaminants in Commencement Bay, Washington, Using Geochemical Signatures
}

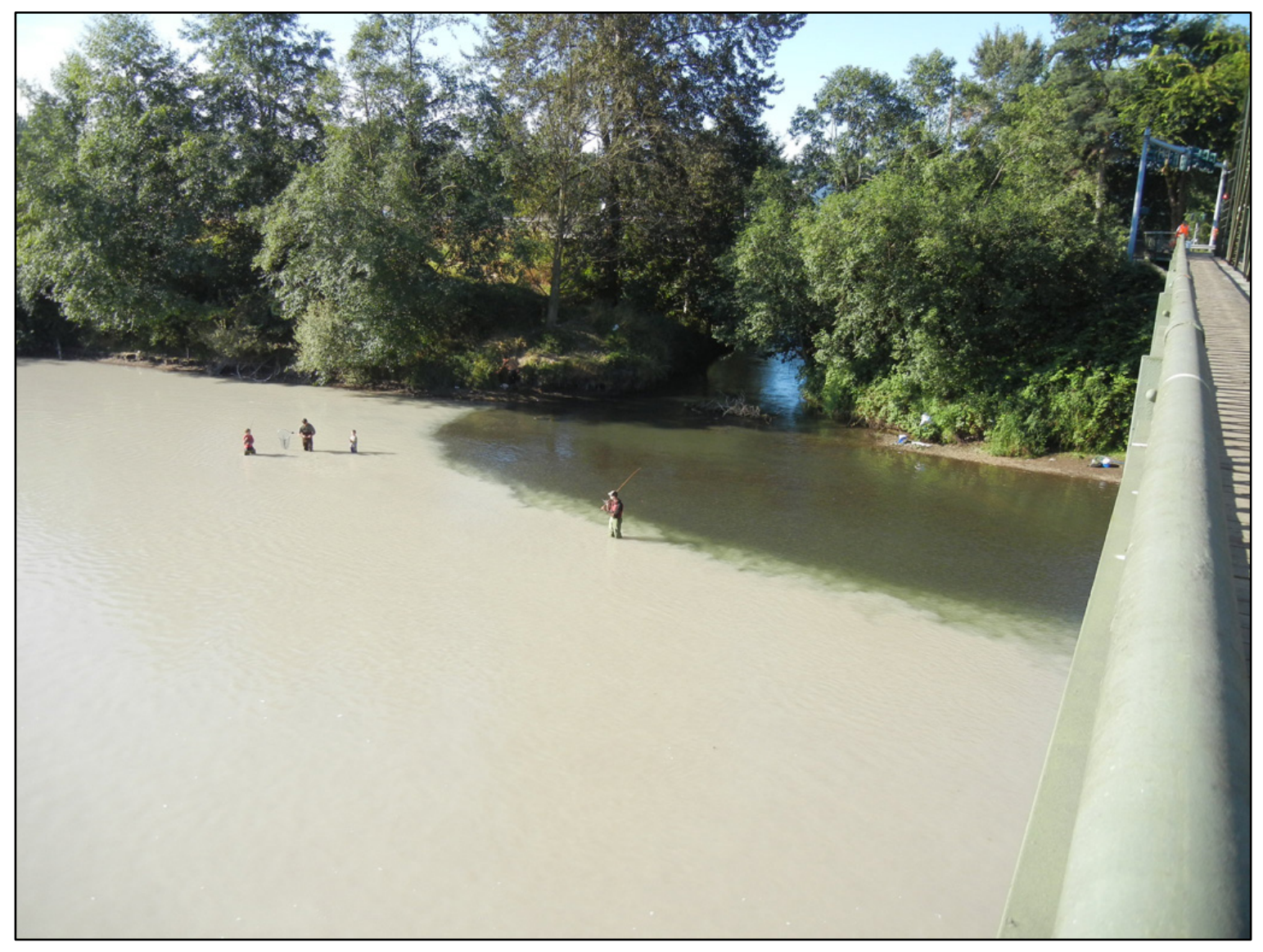

Open-File Report 2017-1124

U.S. Department of the Interior U.S. Geological Survey 
Cover. Photograph of the Puyallup River, Washington, on August 21, 2013 (U.S. Geological Survey photograph by Renee Takesue). 


\section{Tracking Riverborne Sediment and Contaminants in Commencement Bay, Washington, Using Geochemical Signatures}

By Renee K. Takesue, Kathleen E. Conn, and Richard S. Dinicola

Open-File Report 2017-1124

U.S. Department of the Interior

U.S. Geological Survey 


\section{U.S. Department of the Interior \\ RYAN K. ZINKE, Secretary}

\section{U.S. Geological Survey \\ William H. Werkheiser, Acting Director}

U.S. Geological Survey, Reston, Virginia: 2017

For more information on the USGS-the Federal source for science about the Earth, its natural and living resources, natural hazards, and the environment-visit http://www.usgs.gov/ or call 1-888-ASK-USGS (1-888-275-8747).

For an overview of USGS information products, including maps, imagery, and publications, visit http://www.usgs.gov/pubprod/.

Any use of trade, firm, or product names is for descriptive purposes only and does not imply endorsement by the U.S. Government.

Although this information product, for the most part, is in the public domain, it also may contain copyrighted materials as noted in the text. Permission to reproduce copyrighted items must be secured from the copyright owner.

Suggested citation:

Takesue, R.K., Conn, K.E., and Dinicola, R.S., 2017, Tracking riverborne sediment and contaminants in Commencement Bay, Washington, using geochemical signatures: U.S. Geological Survey Open-File Report 20171124, 31 p., https://doi.org/10.3133/ofr20171124.

ISSN 2331-1258 (online) 


\section{Contents}

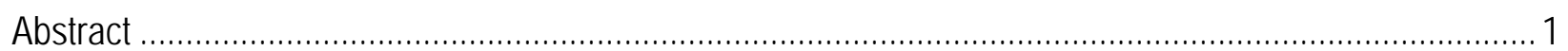

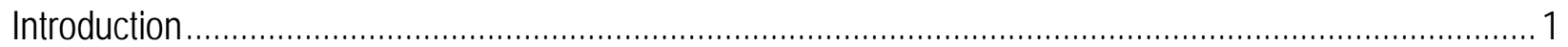

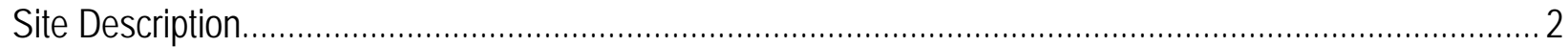

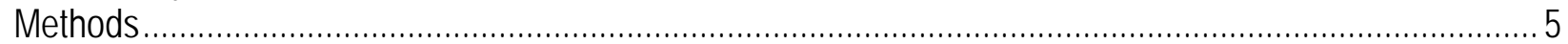

River Discharge and Turbidity ............................................................................................ 5

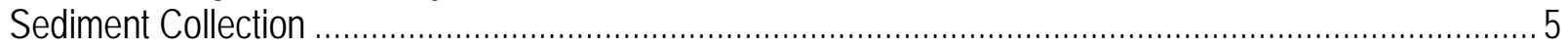

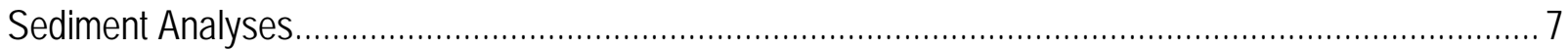

Grain-Size Distribution and Organic-Carbon Content ………..................................................

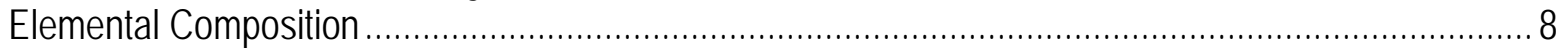

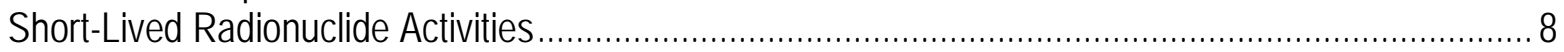

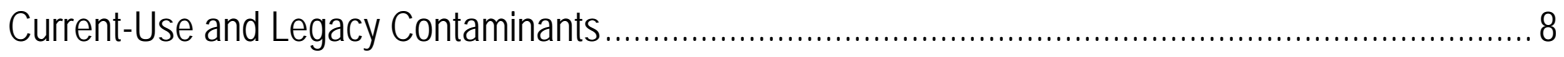

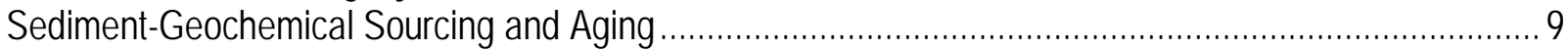

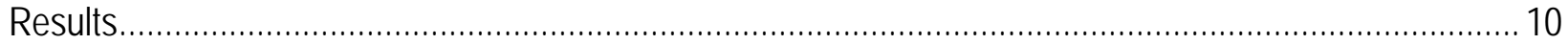

River and Lowland Sediment........................................................................................... 10

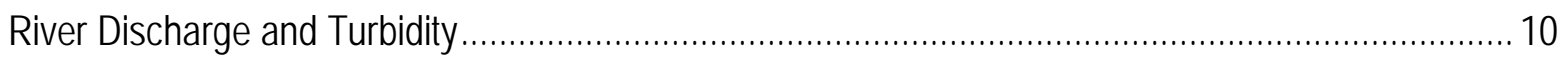

Elemental Compositions of River and Lowland Sediment............................................................ 10

Current-Use and Legacy Contaminants in River Sediment........................................................... 12

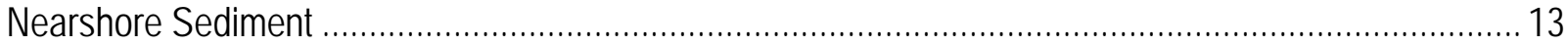

Short-lived Radionuclide Activities in Nearshore Sediment....................................................... 13

Elemental Composition of Nearshore Sediment ........................................................................ 15

Current-Use and Legacy Contaminants in Nearshore Sediment .................................................. 16

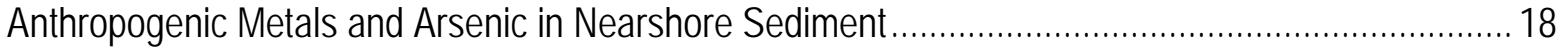

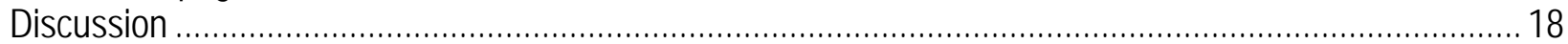

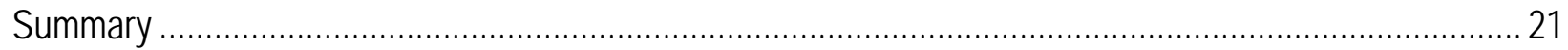

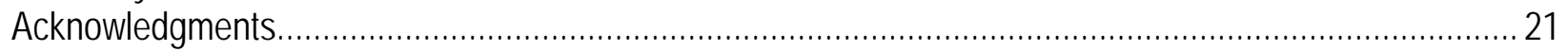

References Cited ............................................................................................................. 21

Appendix 1. Contents of Anthropogenic Metals, Grain-Size Parameters, and Organic Carbon Contents of

Nearshore Fine Sediment Collected in Commencement Bay, Washington, January 28, 2014 ............ 25

Appendix 2. Contents of Aluminum, Barium, and Trace Elements in Fine Sediment Collected from the

Puyallup Watershed, Commencement Bay, and Point Bolin, Washington ......................................... 26

Appendix 3. Radionuclide Activities in Sediment Cores Collected in Commencement Bay, Washington,

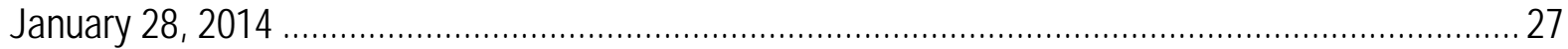

Appendix 4. Chemical Parameters Analyzed by the U.S. Geological Survey National Water Quality

Laboratory in Sediment Collected from the Puyallup and White Rivers and Commencement Bay,

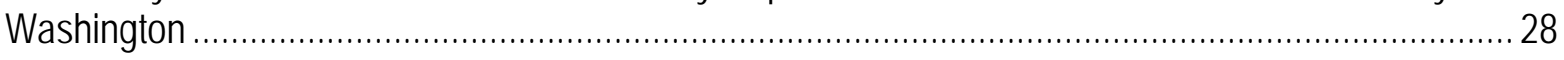

\section{Figures}

1. Annotated Google Earth satellite image of the Puyallup River, Washington, and its tributaries

2. Annotated Google Earth satellite image of Commencement Bay in Puget Sound, Washington, and vicinity showing 2013-14 sediment collection sites (yellow circles). ........... 4

3. Graphs showing time series of median daily discharge in cubic meters per second $\left(\mathrm{m}^{3} / \mathrm{s}\right)$ and median turbidity values in Formazin Nephelometric Units (FNU) in the Puyallup River at Puyallup, Washington (U.S. Geological Survey gaging station 12101500). 
4. Box and whisker plots of aluminum (Al) normalized barium, nickel, and thorium (Ba, $\mathrm{Ni}$, and Th) and the North American shale composite (NASC) normalized lanthanum/ytterbium $\left[(\mathrm{La} / \mathrm{Yb})_{\mathrm{N}}\right]$ ratio in Puyallup and White River (RIV), Puget Lowland (LOW), and Commencement Bay (CB) fine sediment, Puget Sound region, Washington

5. Scatter plots of barium, nickel, and thorium contents relative to aluminum (Al) contents and North American shale composite (NASC) normalized lanthanum (La) to normalized ytterbium (Yb) contents in winter fine sediment from the Puyallup and White Rivers (RIV), Puget Lowland (LOW), and Commencement Bay (CB), Puget Sound region, Washington.. 12

6. Graphs showing variations with depth of short-lived radionuclide activities in disintegrations per minute per gram of dry sediment (dpm/g) in sediment cores from Commencement Bay (CB), Puget Sound, Washington

7. Graphs showing short-lived radionuclide activities in $(A)$ bulk surface layer sediment, (B) surface layer sediment normalized by the total organic carbon content (TOC), (C) in the mixed layer, and $(D)$ in the mixed layer normalized by TOC at five sites in Commencement Bay (CB), Puget Sound, Washington.

8. Plot showing the fraction of Puyallup and White River sediment (RIV) in surface fine sediment from Commencement Bay (CB), Puget Sound, Washington, on January 28, 2014, calculated from two end-member mixing.

9. Graph showing enrichment factors (EF) of anthropogenic elements in fine sediment from Commencement Bay (CB), Puget Sound, Washington, over the geologic background in glacial deposits

10. Graphs comparing contaminant concentrations in winter Puyallup River, Washington, sediment and nearshore sediment for $(A)$ three polycyclic aromatic hydrocarbons, $(B)$ two fecal sterols, $(C)$ two industrial chemicals, and $(D)$ two agricultural chemicals

\section{Tables}

1. Location, collection date, and types of analyses performed on specified sediment size fractions from the Puyallup River watershed and Commencement Bay nearshore sites, Puget Sound, Washington

2. Chemicals detected in more than one Puyallup River, Washington, bar, bank, or suspended sediment sample

3. Chemicals detected in more than one Commencement Bay, Puget Sound, Washington,

fine-sediment sample. 


\section{Conversion Factors}

\begin{tabular}{|c|c|c|}
\hline Multiply & By & To obtain \\
\hline \multicolumn{3}{|c|}{ Length } \\
\hline centimeter $(\mathrm{cm})$ & 0.3937 & inch (in.) \\
\hline millimeter (mm) & 0.03937 & inch (in.) \\
\hline meter $(\mathrm{m})$ & 3.281 & foot (ft) \\
\hline kilometer $(\mathrm{km})$ & 0.6214 & mile (mi) \\
\hline \multicolumn{3}{|c|}{ Area } \\
\hline square kilometer $\left(\mathrm{km}^{2}\right)$ & 247.1 & acre \\
\hline square kilometer $\left(\mathrm{km}^{2}\right)$ & 0.3861 & square mile $\left(\mathrm{mi}^{2}\right)$ \\
\hline \multicolumn{3}{|c|}{ Volume } \\
\hline milliliter $(\mathrm{mL})$ & 0.06102 & cubic inch $\left(\right.$ in $\left.^{3}\right)$ \\
\hline \multicolumn{3}{|c|}{ Flow rate } \\
\hline cubic meter per second $\left(\mathrm{m}^{3} / \mathrm{s}\right)$ & 70.07 & acre-foot per day (acre-ft/d) \\
\hline cubic meter per second $\left(\mathrm{m}^{3} / \mathrm{s}\right)$ & 35.31 & cubic foot per second $\left(\mathrm{ft}^{3} / \mathrm{s}\right)$ \\
\hline cubic meter per second $\left(\mathrm{m}^{3} / \mathrm{s}\right)$ & 22.83 & million gallons per day (Mgal/d) \\
\hline \multicolumn{3}{|c|}{ Mass } \\
\hline microgram $(\mu \mathrm{g})$ & 0.00003527 & ounce, avoirdupois (oz) \\
\hline gram (g) & 0.03527 & ounce, avoirdupois (oz) \\
\hline kilogram (kg) & 2.205 & pound avoirdupois (lb) \\
\hline
\end{tabular}

U.S. customary units to International System of Units

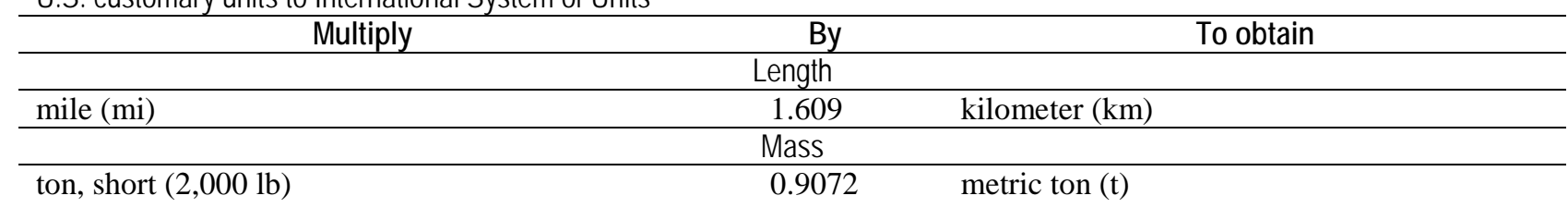

Temperature in degrees Celsius $\left({ }^{\circ} \mathrm{C}\right)$ may be converted to degrees Fahrenheit $\left({ }^{\circ} \mathrm{F}\right)$ as ${ }^{\circ} \mathrm{F}=\left(1.8 \times{ }^{\circ} \mathrm{C}\right)+32$.

Temperature in degrees Fahrenheit $\left({ }^{\circ} \mathrm{F}\right)$ may be converted to degrees Celsius $\left({ }^{\circ} \mathrm{C}\right)$ as ${ }^{\circ} \mathrm{C}=\left({ }^{\circ} \mathrm{F}-32\right) / 1.8$. 


\section{Acronyms and Abbreviations}

\begin{tabular}{|c|c|}
\hline CB & Commencement Bay \\
\hline $\mathrm{dpm} / \mathrm{g}$ & disintegrations per minute per gram of dry sediment \\
\hline EF & enrichment factor \\
\hline ERL & effects range low \\
\hline ERM & effects range median \\
\hline FNU & Formazin Nephelometric Units \\
\hline GS & sediment grain-size distributions (GS) \\
\hline IAEA & International Atomic Energy Association \\
\hline ICP-AES & inductively coupled plasma atomic emission spectrometry \\
\hline ICP-MS & inductively coupled plasma mass spectrometry \\
\hline keV & kiloeletronvolts \\
\hline LOW & Puget Lowland \\
\hline$\mu \mathrm{g} / \mathrm{g}$ & micrograms per gram \\
\hline$\mu \mathrm{g} / \mathrm{kg}$ & micrograms per kilogram \\
\hline MLLW & mean lower low water \\
\hline NASC & North American shale composite \\
\hline NOAA & National Oceanic and Atmospheric Administration \\
\hline NWQL & USGS National Water Quality Laboratory \\
\hline РАН & polycyclic aromatic hydrocarbons \\
\hline PBDE & polybrominated diphenyl ether \\
\hline PCB & polychlorinated biphenyl \\
\hline PCMSC & USGS Pacific Coastal and Marine Science Center \\
\hline ppm & parts per million \\
\hline pcSDSZ & PCMSC in-house statistical software \\
\hline ppm & parts per million \\
\hline RIV & Puyallup and White River \\
\hline $\mathrm{TC}$ & total carbon \\
\hline TIC & total inorganic carbon \\
\hline TOC & total organic carbon \\
\hline USGS & U.S. Geological Survey \\
\hline
\end{tabular}




\section{Chemical Symbols Used}

\begin{tabular}{|c|c|}
\hline Al & aluminum \\
\hline As & arsenic \\
\hline $\mathrm{Ba}$ & barium \\
\hline${ }^{7} \mathrm{Be}$ & beryllium-7 \\
\hline${ }^{214} \mathrm{Bi}$ & bismuth-214 \\
\hline $\mathrm{Cd}$ & cadmium \\
\hline Co & cobalt \\
\hline $\mathrm{Cr}$ & chromium \\
\hline${ }^{137} \mathrm{Cs}$ & cesium-137 \\
\hline $\mathrm{Cu}$ & copper \\
\hline$(\mathrm{La} / \mathrm{Yb})_{\mathrm{N}}$ & normalized lanthanum/ytterbium ratio \\
\hline $\mathrm{Nb}$ & niobium \\
\hline $\mathrm{Ni}$ & nickel \\
\hline $\mathrm{Pb}$ & lead \\
\hline${ }^{210} \mathrm{~Pb}$ & lead-210 \\
\hline${ }^{210} \mathrm{~Pb}_{\mathrm{ex}}$ & excess ${ }^{210} \mathrm{~Pb}$ \\
\hline${ }^{214} \mathrm{~Pb}$ & lead-214 \\
\hline${ }^{226} \mathrm{Ra}$ & radium-226 \\
\hline $\mathrm{Rb}$ & rubidium \\
\hline REE & rare earth elements \\
\hline Sc & scandium \\
\hline $\mathrm{Si}$ & silica \\
\hline Th & thorium \\
\hline Tm & thulium \\
\hline $\mathrm{Zn}$ & zinc \\
\hline $\mathrm{Zr}$ & zirconium \\
\hline
\end{tabular}




\title{
Tracking Riverborne Sediment and Contaminants in Commencement Bay, Washington, Using Geochemical Signatures
}

\author{
By Renee K. Takesue, Kathleen E. Conn, and Richard S. Dinicola
}

\begin{abstract}
Large rivers carry terrestrial sediment, contaminants, and other materials to the coastal zone where they can affect marine biogeochemical cycles and ecosystems. This U.S. Geological Survey study combined river and marine sediment geochemistry and organic contaminant analyses to identify riverborne sediment and associated contaminants at shoreline sites in Commencement Bay, Puget Sound, Washington, that could be used by adult forage fish and other marine organisms. Geochemical signatures distinguished the fine fraction $(<0.063$ millimeter, mm) of Puyallup River sediment — which originates from Mount Rainier, a Cascade volcano - from glacial fine sediment in lowland bluffs that supply sediment to beaches. In combination with activities of beryllium-7 ( $\left.{ }^{7} \mathrm{Be}\right)$, a short-lived radionuclide, geochemical signatures showed that winter 2013-14 sediment runoff from the Puyallup River was transported to and deposited along the north shore of Commencement Bay, then mixed downward into the sediment column. The three Commencement Bay sites at which organic contaminants were measured in surface sediment did not have measurable ${ }^{7} \mathrm{Be}$ activities in that layer, so their contaminant assemblages were attributed to sources from previous years. Concentrations of organic contaminants (the most common of which were polycyclic aromatic hydrocarbons, polychlorinated biphenyls, and fecal sterols) were higher in the $<0.063-\mathrm{mm}$ fraction compared to the $<2$-mm fraction, in winter compared to summer, in river suspended sediment compared to river bar and bank sediment, and in marine sediment compared to river sediment. The geochemical property barium/aluminum (Ba/Al) showed that the median percentage of Puyallup River derived fine surface sediment along the shoreline of Commencement Bay was 77 percent. This finding, in combination with higher concentrations of organic contaminants in marine rather than river sediment, indicates that riverborne sediment-bound contaminants are retained in shallow marine habitats of Commencement Bay. The retention of earlier inputs complicates efforts to identify recent inputs and sources. Understanding modern sources and fates of riverborne sediment and contaminants and their potential ecological impacts will therefore require a suite of targeted geochemical studies in such marine depositional environments.
\end{abstract}

\section{Introduction}

Urbanized coastal watersheds discharge land-derived sediment and contaminants to the coastal ocean from point sources (ditches, outfalls) and nonpoint sources (overland runoff, atmospheric deposition). Particle-bound contaminants can persist for decades to centuries in the 
marine environment, can be transported long distances, and can affect organisms that live in or on the seabed or that ingest sediment while feeding. Thus, understanding the transport and deposition of riverborne sediment and contaminants in the nearshore region is the first step in understanding the risks these materials pose to nearshore organisms, their community structure, and food webs. Geochemical properties of sediment, such as elemental ratios and short-lived radionuclide activities, can distinguish sediments from different geologic sources (Prego and others, 2012) and land-use activities (Matisoff and others, 2002; Fernandez and others, 2006). Once riverborne sediment enters the coastal zone, geochemical tracers can provide insights about dispersal patterns and the recency of deposition (Sommerfield and others, 1999; Fernandez and others, 2006; Prego and others, 2009).

This report describes a study with goals to (1) identify sediment-geochemical signatures that distinguish riverborne fine sediment from the Puyallup River, Washington, from nearshore sediment, (2) determine how fine sediment from the Puyallup River was dispersed in shallow areas of Commencement Bay in Puget Sound following a winter storm, and (3) quantify currentuse and legacy urban contaminants associated with Puyallup River sediment in shallow areas that could be used by beach associated forage fish such as sand lance (Ammodytes personatus) and surf smelt (Hypomesus pretiosus). Forage fish eggs and/or adult fish were found in unconsolidated sediment at eight beaches in and near Commencement Bay during a qualitative site reconnaissance in January 2014. We also report concentrations of (so-called) anthropogenic metals (cadmium, Cd; copper, $\mathrm{Cu}$; lead, $\mathrm{Pb}$, and zinc, $\mathrm{Zn}$ ) and arsenic (As) in nearshore finesediment. Understanding about the fate of riverborne sediment and contaminants in Commencement Bay can identify nearshore areas where nearshore organisms could be at risk from contaminants. Ecological impacts of contaminants are a growing concern (Schwarzenbach and others, 2006) as coastal development increases around Puget Sound (Washington Office of Financial Management, 2016) and worldwide (Mee, 2012).

\section{Site Description}

Puget Sound watersheds fall into two general categories-large river basins with headwaters in the Cascade or Olympic Ranges or local stream drainages. Because the geology of the Cascades and the lowlands differ, so too will the compositions of clastic sediment originating from these source areas. Cascade volcanoes consist of recent intermediate (andesitic) lava flows and tephras overlying intermediate to mafic (basaltic) continental arc basement rocks (Condie and Swenson, 1973; Smith and Leeman, 1993; Sisson and Vallance, 2009). The Puget Lowlands consist of glacial deposits whose sediment was derived from felsic (granitic) batholiths in western British Columbia (Jones, 1999; Crawford and others, 2005). Expected geochemical differences between volcanic upland sediment and glacial lowland sediment form the basis of using sediment-geochemical signatures as a means of discriminating riverborne Puyallup sediment from other sediment in Commencement Bay.

The sediment-geochemical study was undertaken in the Puyallup River watershed in western Washington, and its coastal outlet Commencement Bay in South Puget Sound (fig. 1). The Puyallup River has headwaters in alpine glaciers of Mount Rainier, an active Cascade stratovolcano approximately 65 kilometers $(\mathrm{km})$ (40 miles) from the City of Tacoma (Sisson and Vallance, 2009). The Puyallup River has two main tributaries, the White and Carbon Rivers (fig. 1), and in combination the three rivers drain an area of approximately 2,700 square kilometers

$\left(\mathrm{km}^{2}\right)$ (Czuba and others, 2010). The geology of the Puyallup watershed uplands consists of 
granodiorite basement rocks and Mount Rainier andesite and basaltic-andesite lava flows (Fiske and others, 1964).

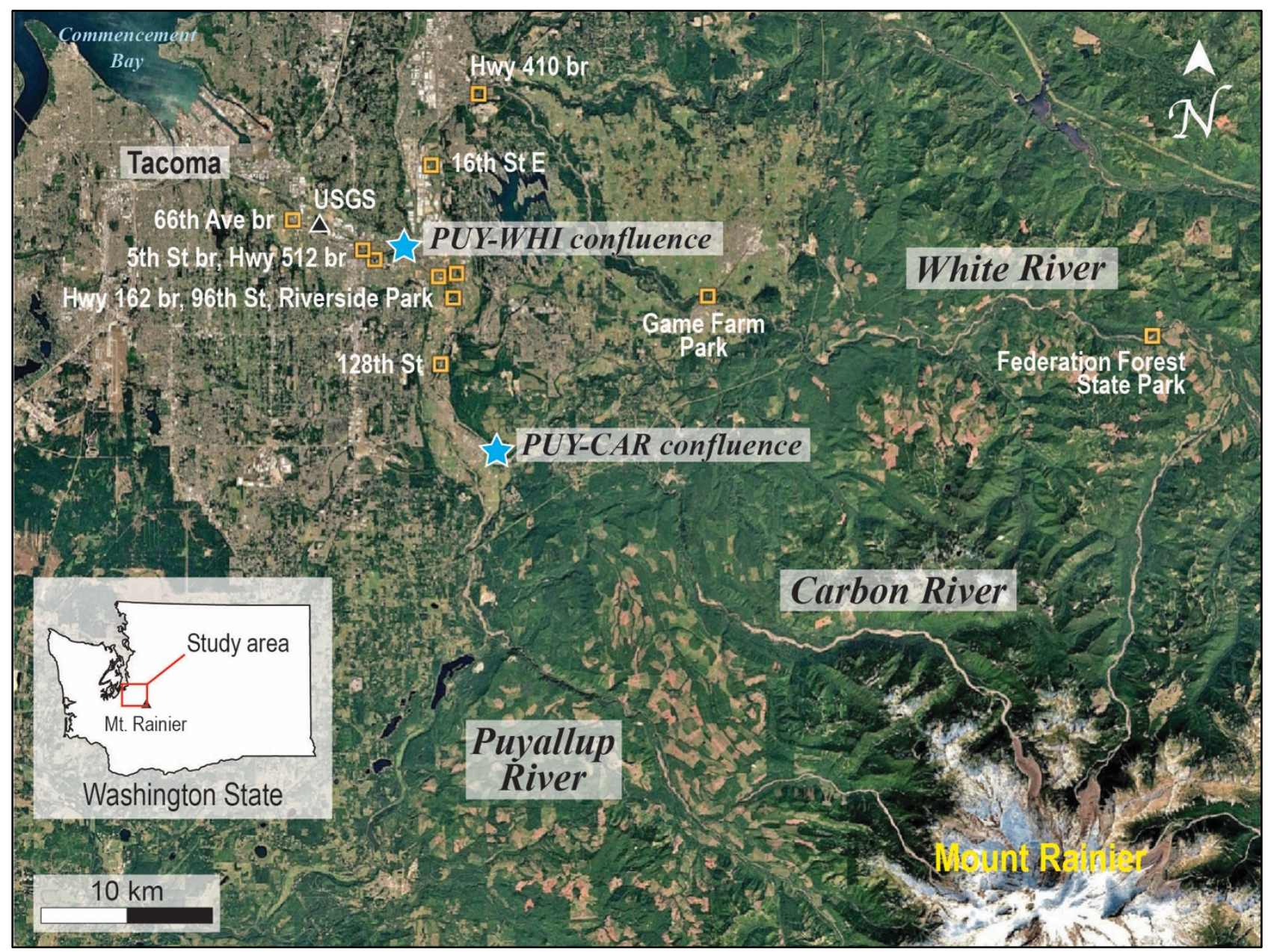

Figure 1. Annotated Google Earth satellite image of the Puyallup River, Washington, and its tributaries. Orange squares show river sediment collection sites, blue stars show the confluences of major tributaries, and the black triangle shows U.S. Geological Survey gaging station 12101500. St, Street; br, bridge; PUY, Puyallup River; WHI, White River; CAR, Carbon River. 
Owing to the volcanic headwaters and the steepness of the watershed (from 4,392 meters, $\mathrm{m}$, elevation at Mount Rainier to sea level within a distance of $65 \mathrm{~km}$ ), the Puyallup River transports large amounts of sediment to the lowlands and Puget Sound. The Puyallup River contributes the third largest annual river sediment load to Puget Sound, an estimated 1,000,000 tons per year (Czuba and others, 2010). Peak discharge of the Puyallup River occurs in winter during storm events, and there is a secondary discharge peak in summer associated with melting snowpack of Mount Rainier glaciers (Czuba and others, 2012). Agricultural, residential, urban, and industrial activities occur in the lower Puyallup River watershed. Runoff in winter is associated with rainfall and consists of sediment and contaminants from the lowlands; runoff in summer is associated with meltwater from glaciers on Mount Rainier and includes glacial flour and contaminants adsorbed during transport.

Commencement Bay is an approximately 20-km², 165-m-deep urban embayment (Ebbesmeyer and others, 1986) at the mouth of the Puyallup River (fig. 2). Tidal flats of the Puyallup River delta were channelized and filled to accommodate railroad, lumber, and shipping industries in the early 1900s and now comprise the Port of Tacoma. A large percentage of the shoreline of Commencement Bay has been armored with rip-rap, eliminating intertidal beach habitat. Cannon and Grigsby (1982) observed the Puyallup River plume exiting Commencement Bay along the northeast shore during ebb tide, whereas near-bottom return flow was along the southwest shore. Ebbesmeyer and others (1986) calculated a water residence time of approximately 15 days for Commencement Bay.

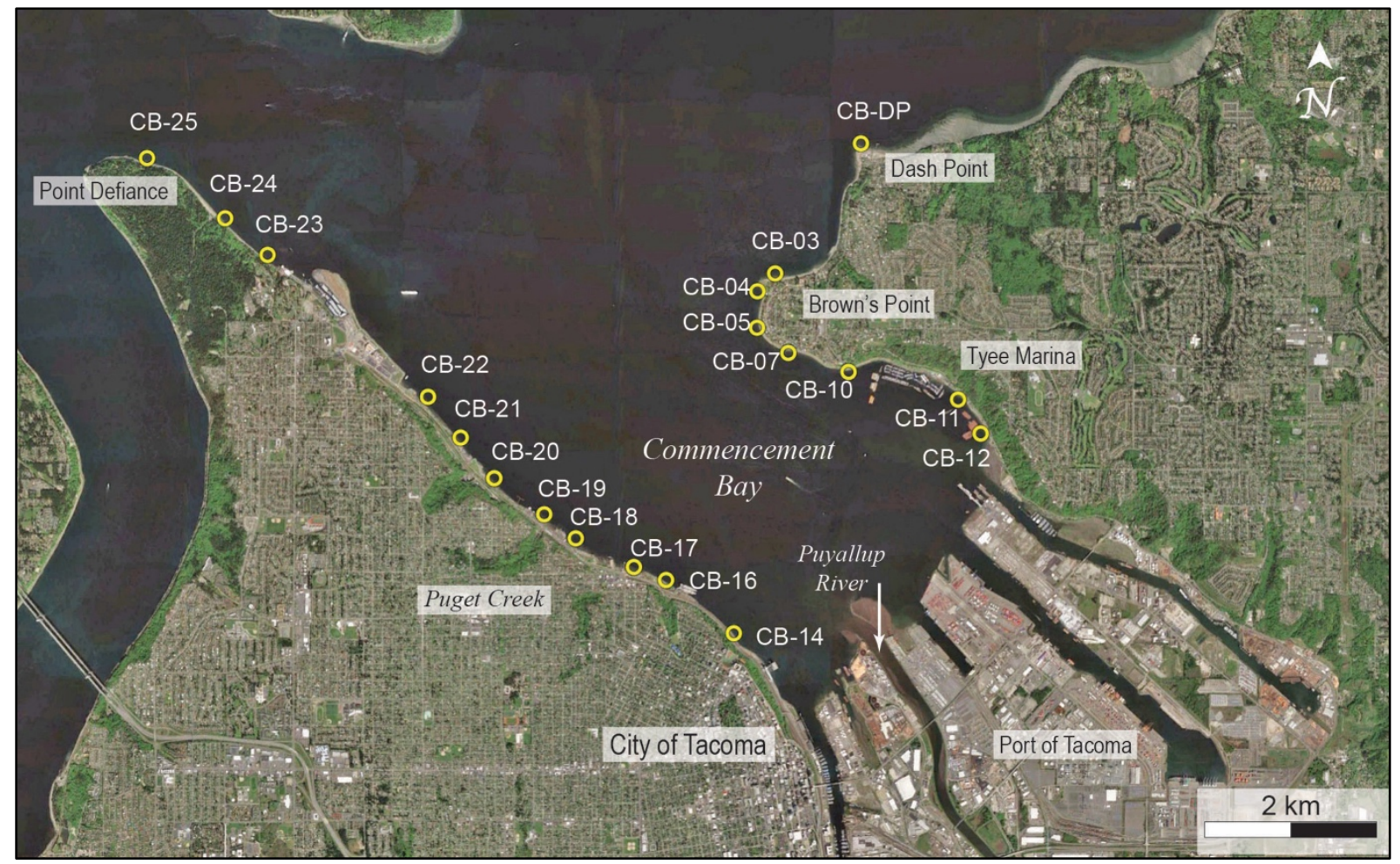

Figure 2. Annotated Google Earth satellite image of Commencement Bay in Puget Sound, Washington, and vicinity showing 2013-14 sediment collection sites (yellow circles). 


\section{Methods}

\section{River Discharge and Turbidity}

Time series of daily river discharge and turbidity were obtained from U.S. Geological Survey (USGS) gaging station 12101500 on the Puyallup River at Puyallup, (see https://waterdata.usgs.gov/nwis/uv?site_no=12101500, accessed May 10, 2017). Turbidity was measured with an infrared optical sidescatter nephelometer (Forest Technology Systems, Digital Turbidity Sensor-12) and reported in Formazin Nephelometric Units (FNU).

\section{Sediment Collection}

River bar and river bank sediment was collected for determination of sediment geochemical signatures and contaminants in the Puyallup and White Rivers (fig. 1) on January 20-21, 2013, August 19-21, 2013, and January 29, 2014 (table 1). Sampling sites on river bars were targeted to areas where fine-grained sediment had accumulated. Particles $>2$ millimeters $(\mathrm{mm})$ in diameter were excluded during sampling. River-bank sediment was collected at the waterline. Sampling was carried out for elemental analyses with a polypropylene scoop and wiretop plastic bags and for organic contaminant analyses with a Teflon ${ }^{\mathrm{TM}}$ spatula and amber glass jars. All samples were stored frozen.

River suspended sediment was collected for contaminant analysis on five occasions between October 2012 and August 2013 from the 66th Avenue bridge on the lower Puyallup River, including during two autumn/winter storm events and three summer glacial melt events. Suspended sediment was collected by pumping large volumes of water from the river through a continuous-flow centrifuge (CFC Express, Scientific Methods, Inc.). The centrifuge captures sediment in the centrifuge bowl and continuously discharges low-sediment water back to the river, as described in Conn and others (2016). 
Table 1. Location, collection date, and types of analyses performed on specified sediment size fractions from the Puyallup River watershed and Commencement Bay nearshore sites, Puget Sound, Washington.

[GEO, geochemistry; RAD, radionuclides; CB, contaminants in bank or bar sediment; CS, contaminants in suspended sediment; GS, grain size; OC, organic carbon content. Date format is Month/Day/Year. mm, millimeter]

\begin{tabular}{|c|c|c|c|c|c|c|c|c|c|}
\hline Site & Latitude & Longitude & Date & GEO & RAD & CB & CS & GS & OC \\
\hline \multicolumn{10}{|c|}{ Puyallup River sediment } \\
\hline $\begin{array}{l}\text { 66th Avenue } \\
\text { bridge }\end{array}$ & 47.21378 & -122.34159 & $\begin{array}{l}10 / 31 / 12 \\
01 / 09 / 13 \\
01 / 20 / 13 \\
06 / 21 / 13 \\
07 / 01 / 13 \\
08 / 06 / 13 \\
08 / 21 / 13 \\
01 / 29 / 14\end{array}$ & $\begin{array}{l}<0.063 \mathrm{~mm} \\
<0.063 \mathrm{~mm}\end{array}$ & & $\begin{array}{l}<2 \mathrm{~mm}, \\
<0.063 \mathrm{~mm} \\
<2 \mathrm{~mm}\end{array}$ & $\begin{array}{l}\text { bulk } \\
\text { bulk } \\
\text { bulk } \\
\text { bulk } \\
\text { bulk }\end{array}$ & $\begin{array}{l}\text { bulk } \\
\text { bulk }\end{array}$ & $\begin{array}{l}\text { bulk, }<2 \mathrm{~mm} \text {, } \\
<0.063 \mathrm{~mm} \\
\text { bulk }\end{array}$ \\
\hline 5th Street bridge & 47.19812 & -122.28708 & $01 / 20 / 13$ & $<0.063 \mathrm{~mm}$ & & & & & \\
\hline Hwy 512 bridge & 47.19321 & -122.28090 & $\begin{array}{l}01 / 20 / 13 \\
08 / 21 / 13\end{array}$ & $\begin{array}{l}<0.063 \mathrm{~mm} \\
<0.063 \mathrm{~mm}\end{array}$ & & & & & \\
\hline Hwy 162 bridge & 47.18479 & -122.22899 & $\begin{array}{l}01 / 21 / 13 \\
08 / 21 / 13 \\
01 / 29 / 14\end{array}$ & $\begin{array}{l}<0.063 \mathrm{~mm} \\
<0.063 \mathrm{~mm} \\
<0.063 \mathrm{~mm}\end{array}$ & & $<2 \mathrm{~mm}$ & & bulk & bulk \\
\hline 96th Street & 47.17334 & -122.21849 & $01 / 21 / 13$ & $<0.063 \mathrm{~mm}$ & & & & & \\
\hline Riverside Park & 47.18634 & -122.21563 & $01 / 29 / 14$ & $<0.063 \mathrm{~mm}$ & & & & bulk & bulk \\
\hline 128th Street & 47.13927 & -122.22780 & $\begin{array}{l}01 / 21 / 13 \\
08 / 21 / 13 \\
\end{array}$ & $\begin{array}{l}<0.063 \mathrm{~mm} \\
<0.063 \mathrm{~mm}\end{array}$ & & & & & \\
\hline \multicolumn{10}{|c|}{ White River sediment } \\
\hline 16th Street East & 47.24289 & -122.23514 & $\begin{array}{l}1 / 21 / 13 \\
1 / 29 / 14\end{array}$ & $\begin{array}{l}<0.063 \mathrm{~mm} \\
<0.063 \mathrm{~mm}\end{array}$ & & $<2 \mathrm{~mm}$ & & bulk & bulk \\
\hline Hwy 410 bridge & 47.17408 & -122.02303 & $\begin{array}{l}8 / 21 / 13 \\
1 / 29 / 14\end{array}$ & $\begin{array}{l}<0.063 \mathrm{~mm} \\
<0.063 \mathrm{~mm}\end{array}$ & & & & bulk & bulk \\
\hline Federation Forest & 47.15200 & -121.68239 & $\begin{array}{l}1 / 21 / 13 \\
8 / 21 / 13 \\
1 / 29 / 14 \\
8 / 21 / 13\end{array}$ & $\begin{array}{l}<0.063 \mathrm{~mm} \\
<0.063 \mathrm{~mm} \\
<0.063 \mathrm{~mm} \\
<0.063 \mathrm{~mm}\end{array}$ & & & & bulk & bulk \\
\hline \multicolumn{10}{|c|}{ Commencement Bay and Nearshore sediment } \\
\hline CB-Dash Point & 47.32032 & -122.42918 & $1 / 28 / 14$ & $<0.063 \mathrm{~mm}$ & & & & bulk & bulk \\
\hline CB-03 & 47.30684 & -122.44231 & $1 / 28 / 14$ & $<0.063 \mathrm{~mm}$ & & & & bulk & bulk \\
\hline CB-04 deep & 47.30498 & -122.44503 & $1 / 28 / 14$ & $<0.063 \mathrm{~mm}$ & bulk & & & bulk & bulk \\
\hline CB-04 shallow & 47.30485 & -122.44471 & $1 / 28 / 14$ & $<0.063 \mathrm{~mm}$ & bulk & $<0.063 \mathrm{~mm}$ & & bulk & bulk \\
\hline CB-05.5 & 47.30121 & -122.44508 & $1 / 28 / 14$ & $<0.063 \mathrm{~mm}$ & & & & bulk & bulk \\
\hline CB-07 & 47.29859 & -122.44030 & $1 / 28 / 14$ & $<0.063 \mathrm{~mm}$ & & & & bulk & bulk \\
\hline CB-10 & 47.29662 & -122.43109 & $1 / 28 / 14$ & $<0.063 \mathrm{~mm}$ & & & & bulk & bulk \\
\hline CB-11 & 47.29374 & -122.41436 & $1 / 28 / 14$ & $<0.063 \mathrm{~mm}$ & bulk & & & bulk & bulk \\
\hline CB-12.5 & 47.29021 & -122.41090 & $1 / 28 / 14$ & $<0.063 \mathrm{~mm}$ & bulk & $<0.063 \mathrm{~mm}$ & & bulk & bulk \\
\hline CB-14 & 47.26951 & -122.44864 & $1 / 28 / 14$ & $<0.063 \mathrm{~mm}$ & & & & bulk & bulk \\
\hline CB-16 & 47.27504 & -122.45899 & $1 / 28 / 14$ & $<0.063 \mathrm{~mm}$ & & & & bulk & bulk \\
\hline CB-17 & 47.27639 & -122.46391 & $1 / 28 / 14$ & $<0.063 \mathrm{~mm}$ & & $<0.063 \mathrm{~mm}$ & & bulk & bulk \\
\hline CB-18 & 47.27936 & -122.47279 & $1 / 28 / 14$ & $<0.063 \mathrm{~mm}$ & bulk & & & bulk & bulk \\
\hline
\end{tabular}




\begin{tabular}{|c|c|c|c|c|c|c|c|c|c|}
\hline Site & Latitude & Longitude & Date & GEO & RAD & $\mathrm{CB}$ & CS & GS & $O C$ \\
\hline CB-19 & 47.28186 & -122.47761 & $1 / 28 / 14$ & $<0.063 \mathrm{~mm}$ & & & & bulk & bulk \\
\hline CB-20 & 47.28560 & -122.48524 & $1 / 28 / 14$ & $<0.063 \mathrm{~mm}$ & & & & bulk & bulk \\
\hline CB-21 & 47.28981 & -122.49039 & $1 / 28 / 14$ & $<0.063 \mathrm{~mm}$ & & & & bulk & bulk \\
\hline CB-22 & 47.29404 & -122.49538 & $1 / 28 / 14$ & $<0.063 \mathrm{~mm}$ & & & & bulk & bulk \\
\hline CB-23 & 47.30876 & -122.51992 & $1 / 28 / 14$ & $<0.063 \mathrm{~mm}$ & & & & bulk & bulk \\
\hline CB-25 & 47.31879 & -122.53837 & $1 / 28 / 14$ & $<0.063 \mathrm{~mm}$ & & & & bulk & bulk \\
\hline Point Defiance & 47.31473 & -122.53002 & 8/19/13 & $<0.063 \mathrm{~mm}$ & & & & bulk & bulk \\
\hline Dockton & 47.37151 & -122.45670 & $8 / 20 / 13$ & $<0.063 \mathrm{~mm}$ & & $\begin{array}{l}<2 \mathrm{~mm}, \\
<0.063 \mathrm{~mm}\end{array}$ & & bulk & $\begin{array}{l}\text { bulk, }<2 \mathrm{~mm}, \\
<0.063 \mathrm{~mm}\end{array}$ \\
\hline \multicolumn{10}{|c|}{ Glacial sediment } \\
\hline Point Bolin, bluff & 47.69066 & -122.59193 & $6 / 25 / 13$ & $<0.063 \mathrm{~mm}$ & & & & bulk & \\
\hline Point Bolin, slide & 47.69646 & -122.60348 & $6 / 25 / 13$ & $<0.063 \mathrm{~mm}$ & & & & bulk & \\
\hline Point Bolin, bluff & 47.69646 & -122.60348 & $6 / 25 / 13$ & $<0.063 \mathrm{~mm}$ & & & & bulk & \\
\hline $\begin{array}{l}\text { Point Defiance, } \\
\text { clay }\end{array}$ & 47.31761 & -122.53459 & $8 / 19 / 13$ & $<0.063 \mathrm{~mm}$ & & & & bulk & \\
\hline
\end{tabular}

Nearshore sediment was collected at 18 sites along the shoreline of Commencement Bay (fig. 2, table 1), including Browns Point, on January 28, 2014, shortly after a winter storm. A stainless steel van Veen-type benthic sampler was deployed from a small boat to collect bottom sediment close to the shore. Water depth from the vessel's depth finder and the predicted tidal height indicated that bottom sediment was collected at depths ranging from $-1.0 \mathrm{~m}$ relative to mean lower low water (MLLW) to -15.7 m MLLW. The median sampling depth was $-3.1 \mathrm{~m}$ MLLW. The upper 0-2 centimeters $(\mathrm{cm})$ of the intact sediment surface was subsampled for geochemistry and contaminants from the material in the benthic sampler. Sediment for radionuclide analyses was collected at five sites whose sediment appeared muddy at the time of sampling-CB-04 (shallow), CB-04 (deep), CB-11, CB-12.5, and CB-18 (fig. 2) by emplacing a 3.5-cm-diameter polycarbonate core barrel in the benthic sampler to recover a short sediment column (as long as $12 \mathrm{~cm}$ ). A reconnaissance sample of nearshore sediment was also collected on August 20, 2013, in Quartermaster Harbor (not shown), a nearby Puget Sound embayment that receives sediment from the Puyallup River plume.

Glacial sediment was collected from three subaerial bluffs above the high-tide line on the west side of Point Bolin, Kitsap County, and a clay layer exposed in the intertidal beach face at Point Defiance, Pierce County (table 1).

\section{Sediment Analyses}

\section{Grain-Size Distribution and Organic-Carbon Content}

Sediment grain-size distributions (GS) were determined at the USGS Pacific Coastal and Marine Science Center (PCMSC) sediment laboratory in Santa Cruz, California, on organic- and salt-free sediment using a combination of techniques. Particles coarser than gravel $(>2 \mathrm{~mm})$ were quantified by dry sieving at quarter-phi intervals ( particles (2-0.063 $\mathrm{mm}$ and $<0.063 \mathrm{~mm}$, respectively) were separated by wet sieving and quantified using a laser particle diffraction counter (Beckman Coulter Life Sciences). GS parameters were calculated with in-house statistical software (pcSDSZ) according to the methods 
of Folk and Ward (1957). Total carbon (TC) and total inorganic carbon (TIC) were determined coulometrically (UIC, Inc.) in the surface $0-2 \mathrm{~cm}$ layer at each site. Total organic carbon (TOC) was calculated as the difference between TC and TIC. Grain size and organic carbon results are tabulated in appendix 1.

\section{Elemental Composition}

A subsample of bulk sediment was oven-dried at 60 degrees Celsius $\left({ }^{\circ} \mathrm{C}\right)$, disaggregated in a mortar and pestle, and dry-sieved in stainless steel sieves to obtain 2 grams ( $\mathrm{g}$ ) of the $<0.063-\mathrm{mm}$ fine fraction (silt and clay). The sediment fine fraction was sent to SGS, Inc., a nationally recognized testing laboratory, for quantification of major, minor, and trace elements, including anthropogenic metals and rare earth elements (REEs), using a sodium peroxide sinter followed by quantification by inductively coupled plasma mass spectrometry (ICP-MS) and inductively coupled plasma atomic emission spectrometry (ICP-AES). The reproducibility of three replicate samples submitted to SGS, Inc., was better than 10 percent for all target elements except the heavy REE thulium (Tm), which had a reproducibility of 12 percent. A second procedure that targeted trace elements used a four-acid near-total sediment decomposition followed by quantification by ICP-MS (Briggs and Meier, 2002). Neither analytical method quantified silica (Si) contents. Major element contents are reported in units of percent (\%) and minor and trace element contents as parts per million (ppm), which is equivalent to micrograms per gram $(\mu \mathrm{g} / \mathrm{g})$. Total element contents were normalized to Al to account for differences in grain size. REE contents were normalized to a North American shale composite (NASC), which represents the composition of average sedimentary rock (McLennan, 1989). Normalized values were used to calculate REE ratios. Contents of anthropogenic elements in a glacial clay bed in Commencement Bay were used to define natural geologic levels, or backgrounds, of these elements because there were no anthropogenic influences on their contents at the time of deposition. Elemental compositions are tabulated in appendix 2.

\section{Short-Lived Radionuclide Activities}

Sediment cores as long as $12 \mathrm{~cm}$ were sectioned into 2-cm-thick intervals 1 day after collection and refrigerated. At the PCMSC radionuclide laboratory, sediment was oven-dried (60 ${ }^{\circ} \mathrm{C}$ ), disaggregated, packed into 10-milliliter (mL) vials, and counted on an ultra-lowbackground, high-purity germanium well detector for 24 hours. Lead-210 $\left({ }^{210} \mathrm{~Pb}\right)$ was measured at 46.5 kiloeletronvolts (keV); radium-226 $\left({ }^{226} \mathrm{Ra}\right)$ was measured at 351.87 (lead-214, $\left.{ }^{214} \mathrm{~Pb}\right)$ and 609.31 (bismuth-214, ${ }^{214} \mathrm{Bi}$ ) keV; cesium-137 $\left({ }^{137} \mathrm{Cs}\right.$ ) was measured at $661 \mathrm{keV}$; and ${ }^{7} \mathrm{Be}$ was measured at $477.56 \mathrm{keV}$. Detectors were regularly calibrated with standards from the International Atomic Energy Association (IAEA)_IAEA-RGU-1, IAEA-RGTH-1, and IAEA 300 prepared in the same geometry as samples. Geologically unsupported, or excess, ${ }^{210} \mathrm{~Pb}$ (abbreviated as ${ }^{210} \mathrm{~Pb}_{\mathrm{ex}}$ ) was calculated by subtracting supported ${ }^{210} \mathrm{~Pb}$ (from its parent ${ }^{226} \mathrm{Ra}$ ) from the total ${ }^{210} \mathrm{~Pb}$ activity. Radionuclide activities are tabulated in appendix 3.

\section{Current-Use and Legacy Contaminants}

Sediment samples were analyzed at the USGS National Water Quality Laboratory (NWQL) for a suite of organic contaminants including PAHs by NWQL schedule 5506 (Zaugg and others, 2006), waste indicator chemicals by NWQL schedule 5433 (Burkhardt and others, 2006), hormones by NWQL schedule 6434 modified from Foreman and others (2012), and 
halogenated organic compounds including select PCB congeners and polybrominated diphenyl ether (PBDE) congeners by NWQL lab code 8093, a research method described in Wagner and others (2014). A complete list of analyzed parameters is in appendix 4. When a parameter was analyzed by multiple methods, results are reported from the most sensitive method. In this report, detections and maximum concentrations are reported when the concentration is above the longterm NWQL method detection limit and at least three times greater than the associated laboratory blank sample. Results are reported on a dry-weight basis. Contaminant data can be found at the USGS National Water Information System-Web Interface (see http://dx.doi.org/10.5066/F7P55KJN, accessed September 25, 2017).

\section{Sediment-Geochemical Sourcing and Aging}

Immobile and relatively immobile elements, those that are minimally altered during sediment erosion and transport, form the most effective geochemical signatures because they reflect the source-rock compositions. These elements include the trace elements barium, cobalt, chromium, nickel, niobium, rubidium, scandium, thorium, and zirconium (Ba, $\mathrm{Co}, \mathrm{Cr}, \mathrm{Ni}, \mathrm{Nb}$, $\mathrm{Rb}, \mathrm{Sc}, \mathrm{Th}, \mathrm{Zr}$ ), as well as the REE and their ratios (McLennan and others, 1990). Elements that had statistically different mean values in river and glacial sediment were identified with two tailed Student's $t$-tests and $p$-values $<0.01$ using StatPlusPro software. Geochemical signatures in river sediment collected during January 2013 and 2014 ( $n=13$; table 1) were used to define a river end-member representative of terrestrial sediment deposited in Commencement Bay in January 2014. Four samples from glacial deposits were used to define an end-member representative of Puget Lowland sediment. It was assumed that the inorganic fraction of nearshore sediment in Commencement Bay was primarily a mixture of material derived from riverine and glacial sources.

Activities of short-lived radionuclides ${ }^{7} \mathrm{Be},{ }^{137} \mathrm{Cs}$, and ${ }^{210} \mathrm{~Pb}$ in bulk sediment can indicate how recently terrestrial sediment was deposited in the coastal region. ${ }^{7} \mathrm{Be}$, with a 53.2-day halflife $\left(t_{1 / 2}\right)$, is primarily used as a runoff indicator to track sedimentation events that occurred as many as 5 months before sampling (Sommerfield and others, 1999). ${ }^{137} \mathrm{Cs}\left(t_{1 / 2}=30.2\right.$ years) is a radionuclide produced by thermonuclear weapons testing between the mid-1950s and mid-1980s (Garcia-Agudo, 1998). Its presence indicates sediment deposited during that interval or mixtures of such sediment. Excess ${ }^{210} \mathrm{~Pb}\left(t_{1 / 2}=22.2\right.$ years $)$ in the sediment column indicates the presence of sediment deposited within the past 100 years (Carpenter and others, 1985). Radionuclide activities were assessed in surface sediments (depth of $0-2 \mathrm{~cm}$ ), the interval in which organic contaminants and anthropogenic metals were measured, to link nearshore contaminant assemblages with terrestrial runoff from recent winter storms. To account for potential vertical redistribution of radionuclides by mixing processes, radionuclide activities were also summed in the sediment mixed layer, here limited to a depth of $0-8 \mathrm{~cm}$, the maximum core length recovered in four of five sediment cores. To account for differences in TOC contents among sites, radionuclide activities were normalized to the bulk sediment TOC content of the surface $0-2 \mathrm{~cm}$ layer at each site, the only interval in which TOC was determined. The sediment core at CB-04$\mathrm{D}$ was only $4 \mathrm{~cm}$ long, so the radionuclide inventory calculated there is a minimum estimate of the total activity over an 8-cm-long sediment column. 


\section{Results}

\section{River and Lowland Sediment}

The resulting data for river and lowland sediment include river discharge and turbidity, elemental composition of river and lowland sediment, and organic contaminants in river sediment.

River Discharge and Turbidity

Daily discharge of the Puyallup River at Puyallup, Washington (USGS gaging station 12101500), approximately $11 \mathrm{~km}$ upstream of the river mouth, was generally similar in January 2013 (winter 2013, W13) and 2014 (winter 2014, W14) in the months preceding sediment collection, whereas median daily turbidity was higher in W13 (fig. 3). Discharge and turbidity were seasonally out of phase: median turbidity levels were low in winter when discharge was high and vice versa in summer. Sediment sampling in the summer 2013 (S13) occurred during the period of glacial runoff (fig. 3).

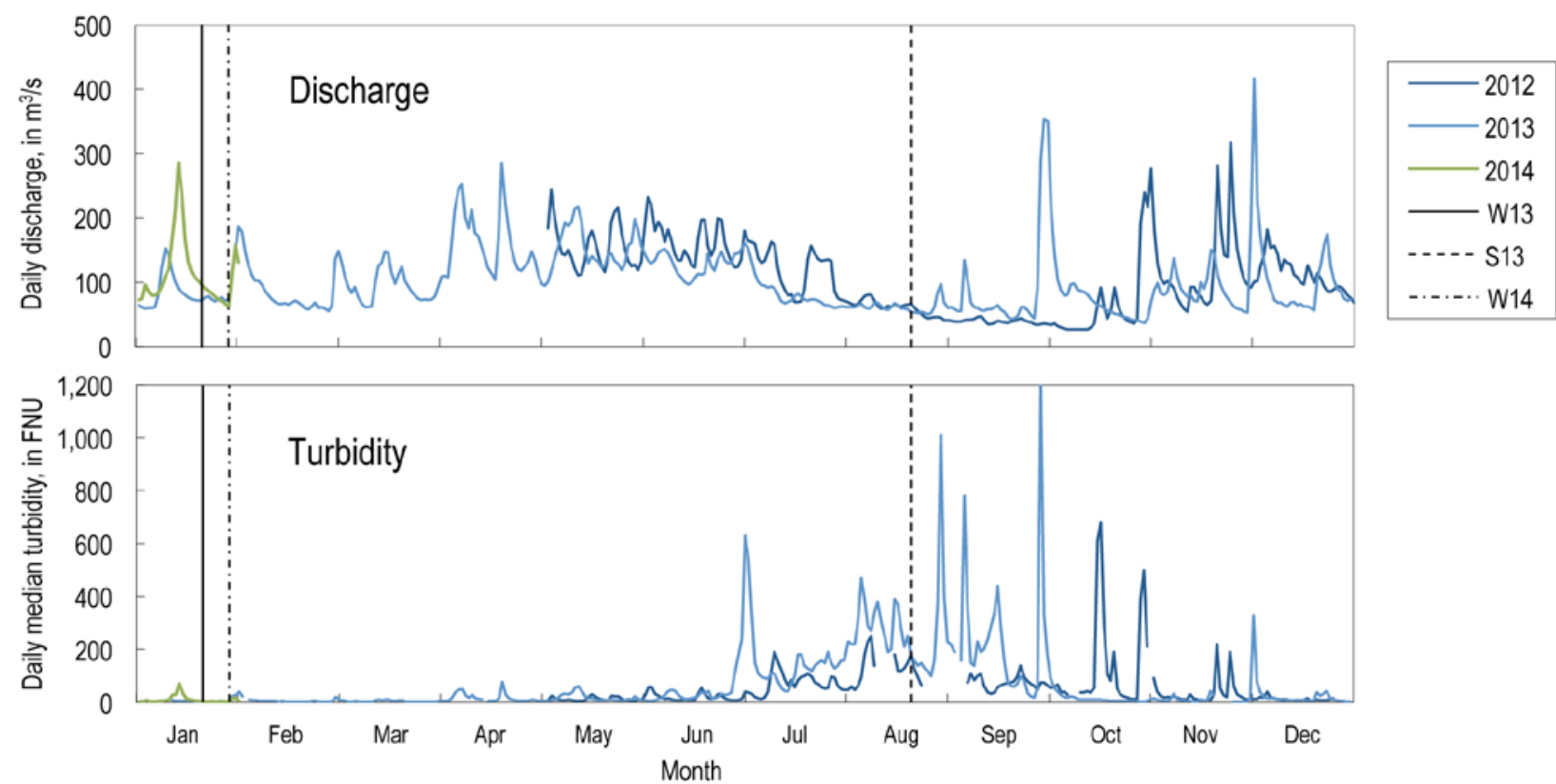

Figure 3. Graphs showing time series of median daily discharge in cubic meters per second $\left(\mathrm{m}^{3} / \mathrm{s}\right)$ and median turbidity values in Formazin Nephelometric Units (FNU) in the Puyallup River at Puyallup, Washington (U.S. Geological Survey gaging station 12101500). Vertical lines show sediment collection dates-January 20, 2013 (winter 2013, W13), August 21, 2013 (summer 2013, S13), and January 28, 2014 (winter 2014, W14).

\section{Elemental Compositions of River and Lowland Sediment}

Among the immobile and relatively immobile elements used to identify geochemical source signatures, four had significantly different means between winter river sediment (RIV, Puyallup and White Rivers) and Puget Lowland sediment (LOW, glacial bluffs and clay)—Alnormalized contents of $\mathrm{Ba}, \mathrm{Ni}$, and $\mathrm{Th}$, and the NASC-normalized REE ratio lanthanum/ytterbium- $(\mathrm{La} / \mathrm{Yb})_{\mathrm{N}}$. Descriptive statistics for these parameters are summarized in 
figure 4 , and the raw data are shown in figure $5 . \mathrm{Ba} / \mathrm{Al}$ had the lowest coefficients of variation ( $\mathrm{CV}$, defined as ratio of the standard deviation to the mean), in RIV (0.05) and LOW (0.02), indicating that sediment sources were very well constrained with this parameter. In comparison, the CVs were more than two times higher for $\mathrm{Ni} / \mathrm{Al}(0.31,0.06), \mathrm{Th} / \mathrm{Al}(0.14,0.04)$, and $(\mathrm{La} / \mathrm{Yb})_{\mathrm{N}}(0.12,0.09)$ than for $\mathrm{Ba} / \mathrm{Al}$. Some of the geochemical variability was related to compositional differences between Puyallup and White River sediment and some to differences between the two years. Ba/Al values were normally distributed in the two end members (Shaprio-Wilk test, $p=0.54, \alpha=0.05$ ), so mean $\mathrm{Ba} / \mathrm{Al}$ values of RIV and LOW were used as geochemical signatures $\left[\mathrm{Ba} / \mathrm{Al}_{\mathrm{RIV}}=41 \pm 2(\right.$ mean $\left.\pm 1 \sigma), \mathrm{Ba} / \mathrm{Al}_{\mathrm{LOW}}=65 \pm 1\right]$ to estimate fractions of river-derived sediment in the nearshore.
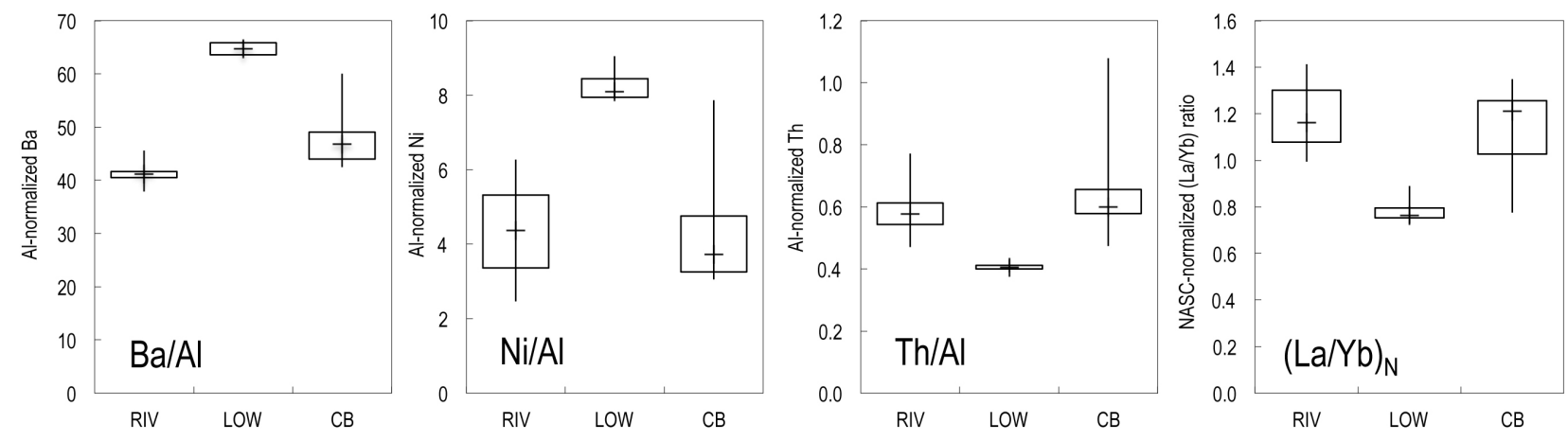

Figure 4. Box and whisker plots of aluminum (Al) normalized barium, nickel, and thorium ( $\mathrm{Ba}, \mathrm{Ni}$, and $\mathrm{Th})$ and the North American shale composite (NASC) normalized lanthanum/ytterbium $\left[(\mathrm{La} / \mathrm{Yb})_{N}\right]$ ratio in Puyallup and White River (RIV), Puget Lowland (LOW), and Commencement Bay (CB) fine sediment, Puget Sound region, Washington. Box heights show the interquartile ranges, whiskers show maxima and minima, and lines crossing whiskers show medians. 

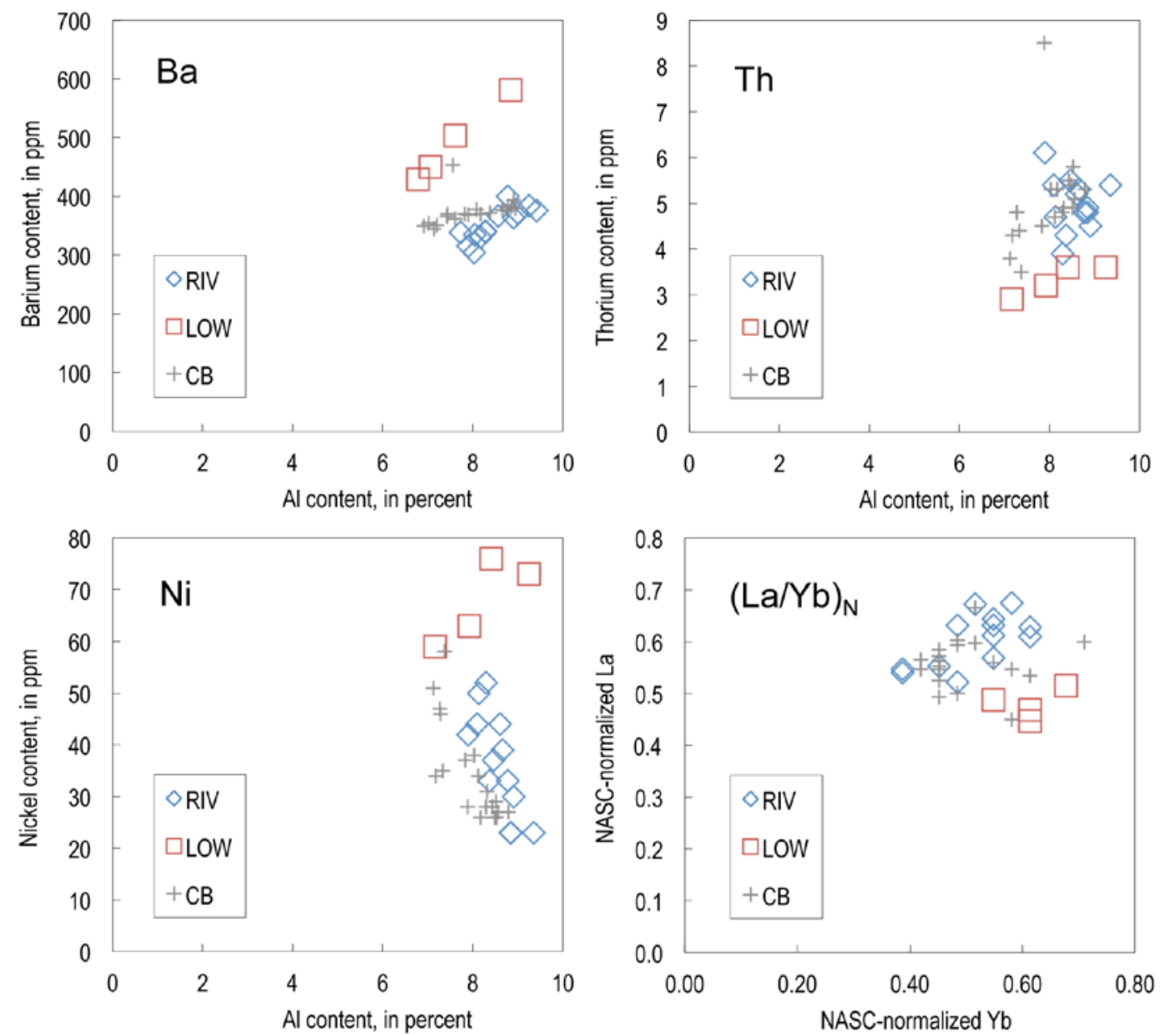

Figure 5. Scatter plots of barium, nickel, and thorium contents relative to aluminum (Al) contents and North American shale composite (NASC) normalized lanthanum (La) to normalized ytterbium (Yb) contents in winter fine sediment from the Puyallup and White Rivers (RIV), Puget Lowland (LOW), and Commencement Bay (CB), Puget Sound region, Washington. ppm, parts per million.

\section{Current-Use and Legacy Contaminants in River Sediment}

Table 2 lists the 14 compounds that were detected in more than one river-bar or riverbank sediment or suspended-sediment sample. Two fecal sterols were the most frequently detected organic chemicals in river sediment-cholesterol (6/7 detections, concentrations ranging from an estimated 223 micrograms per kilogram, $\mu \mathrm{g} / \mathrm{kg}$, to $678 \mu \mathrm{g} / \mathrm{kg})$ and $\beta$-sitosterol (6/6 detections, concentrations ranging from an estimated $1,520 \mu \mathrm{g} / \mathrm{kg}$ to an estimated 2,350 $\mu \mathrm{g} / \mathrm{kg}$ ). In addition, the biocide degradate pentachloroanisole was detected in three winter samples. Other chemicals were detected singly and (or) sporadically.

Ten (of 157) organic chemicals were detected in one or more of the four samples for which the $<2$-mm fraction was analyzed-four PAHs, three waste indicators, two hormones, and one halogenated compound. Nine of the ten compounds were detected in river-bank sediment collected during winter 2013 at the Highway 162 bridge (Puyallup River upstream of the confluence with the White River). One to four chemicals were detected in the $<2$-mm fraction of river-bar and riverbank sediment collected from the White River in winter 2014 and the 66th Avenue bridge (lower Puyallup River below the White River confluence) in summer 2013 and 
winter 2014. When a fine-sediment $(<0.063 \mathrm{~mm})$ subsample was analyzed and compared to the corresponding $<2-\mathrm{mm}$ fraction at the 66th Avenue bridge during the summer sampling, three additional compounds were detected at low concentrations - the hormone 17- $\alpha$-estradiol and the flame retardants PBDE 47 and PBDE 99.

More organic chemicals were detected in river suspended sediment than in river-bar or riverbank sediment. Twenty-seven (of 147) organic chemicals were detected in one or more river suspended-sediment samples collected from the 66th Avenue bridge on the lower Puyallup River. This included 13 PAHs, 7 waste indicators, and 7 halogenated organic compounds (suspended sediment samples were not analyzed for hormones). Similar to the river-bar and riverbank sediment samples, more compounds were detected in the winter samples (12 to 14 compounds detected) than in the summer samples (1, 2, and 8 compounds detected).

Table 2. Chemicals detected in more than one Puyallup River, Washington, bar, bank, or suspended sediment sample.

$\underline{[\mu \mathrm{g} / \mathrm{kg}, \text { microgram per kilogram dry weight; E, estimated.] }}$

\begin{tabular}{|c|c|c|c|}
\hline \multirow[b]{2}{*}{ Chemical } & \multirow[b]{2}{*}{$\begin{array}{c}\text { Maximum } \\
\text { detected } \\
\text { concentration } \\
(\mu \mathrm{g} / \mathrm{kg})\end{array}$} & \multicolumn{2}{|c|}{ Number of detects or samples } \\
\hline & & $\begin{array}{l}\text { River-bar or } \\
\text { riverbank } \\
\text { sediment }\end{array}$ & $\begin{array}{c}\text { River } \\
\text { suspended } \\
\text { sediment }\end{array}$ \\
\hline \multicolumn{4}{|c|}{ Polycyclic aromatic hydrocarbons } \\
\hline 1,6-Dimethylnaphthalene & E15.2 & $2 / 5$ & $2 / 5$ \\
\hline 1-Methylphenanthrene & 17.1 & $1 / 5$ & $2 / 5$ \\
\hline 2,6-Dimethylnaphthalene & 18.8 & $1 / 5$ & $3 / 5$ \\
\hline Fluoranthene & 34.1 & $0 / 5$ & $2 / 5$ \\
\hline Naphthalene & E5.9 & $0 / 5$ & $2 / 5$ \\
\hline \multicolumn{4}{|c|}{ Waste indicators and hormones } \\
\hline 4-Cumylphenol & 71.9 & $0 / 3$ & $2 / 3$ \\
\hline Bisphenol A & E489 & $0 / 3$ & $2 / 2$ \\
\hline Cholesterol & E678 & $5 / 5$ & $2 / 3$ \\
\hline Indole & 142 & $1 / 5$ & $1 / 3$ \\
\hline Phenol & E548 & $1 / 5$ & $1 / 3$ \\
\hline$\beta$-sitosterol & E2350 & $3 / 3$ & $2 / 2$ \\
\hline \multicolumn{4}{|c|}{ Halo-organic compounds } \\
\hline Pentachloroanisole & 0.14 & $2 / 4$ & $1 / 5$ \\
\hline Polybrominated diphenyl ether 47 & E0.93 & $1 / 4$ & $1 / 5$ \\
\hline Polybrominated diphenyl ether 99 & 0.16 & $1 / 5$ & $1 / 5$ \\
\hline
\end{tabular}

\section{Nearshore Sediment}

The resulting data for nearshore sediment include short-lived radionuclide activities, elemental composition, organic contaminants, and anthropogenic metals and arsenic.

Short-lived Radionuclide Activities in Nearshore Sediment

Profiles of excess ${ }^{210} \mathrm{~Pb}$ showed no trend with depth in sediment cores, indicating that the sediment column up to a depth of 12-cm was vertically mixed (fig. 6) and thus not useful for estimating ${ }^{210} \mathrm{~Pb}$-based sediment accumulation rates. ${ }^{137} \mathrm{Cs}$ activities in the sediment column were 
low and akin to background levels measured by Davis and others (1997) in Commencement Bay (CB) waterways.
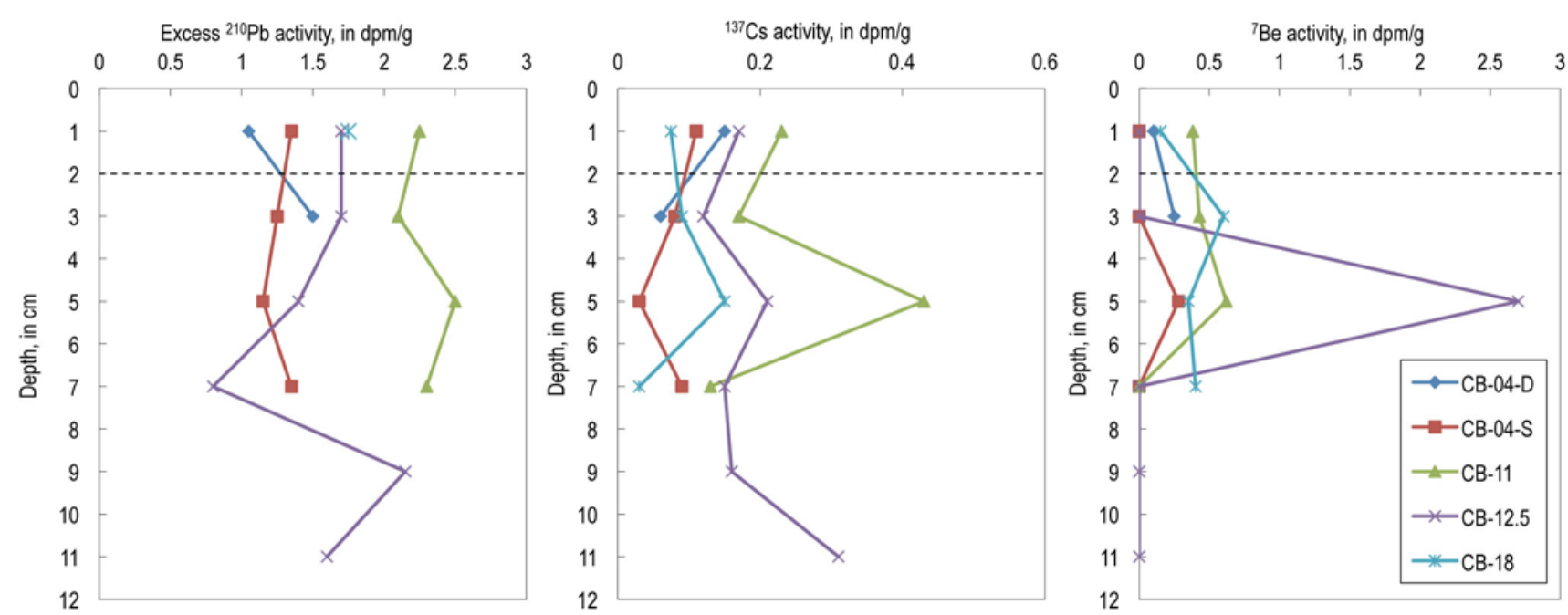

Figure 6. Graphs showing variations with depth of short-lived radionuclide activities in disintegrations per minute per gram of dry sediment (dpm/g) in sediment cores from Commencement Bay (CB), Puget Sound, Washington. Downcore values were measured in 2 centimeter $(\mathrm{cm})$ thick sections and are plotted at midpoints of intervals. Dashed lines indicate the bottom of the surface layer of sediment.

Three sites had surface sediment with measurable ${ }^{7}$ Be activities_-CB-04-D (-15.7 m MLLW) at Browns Point, CB-11 (-2.7 m MLLW) on the north shore near Tyee Marina, and CB18 (likely -5 m MLLW) offshore of Puget Creek on the south shore (fig. 7A). Sites CB-04-S (7.6 m MLLW) and CB-12.5 (-2.6 m MLLW, adjacent to a floating log corral) had no measurable ${ }^{7} \mathrm{Be}$ in the surface layer. Among these sites, the bulk-sediment TOC varied from 0.6 percent at CB-04-D to 11.5 percent at CB-18. TOC-normalized radionuclide activities were highest at CB-04-D (Browns Point) (fig. 7B), suggesting that this site experienced the most recent sediment deposition. Normalized radionuclide activities increased from the inner bay to the outer bay along the north shore (fig. $7 B$ ), similar to the manner in which the Puyallup River runoff plume is often observed to flow. There are no local drainages ( ${ }^{7}$ Be sources) along the north shore of Commencement Bay between CB-04 and CB-12.5 suggesting that ${ }^{7} \mathrm{Be}$ in surface sediment at CB-04-D and CB-11 was from recent Puyallup River outflow and deposition. Measurable ${ }^{7}$ Be-containing sediment at CB-18 may have originated in whole or in part from Puget Creek, a local drainage on the south shore of the bay. 

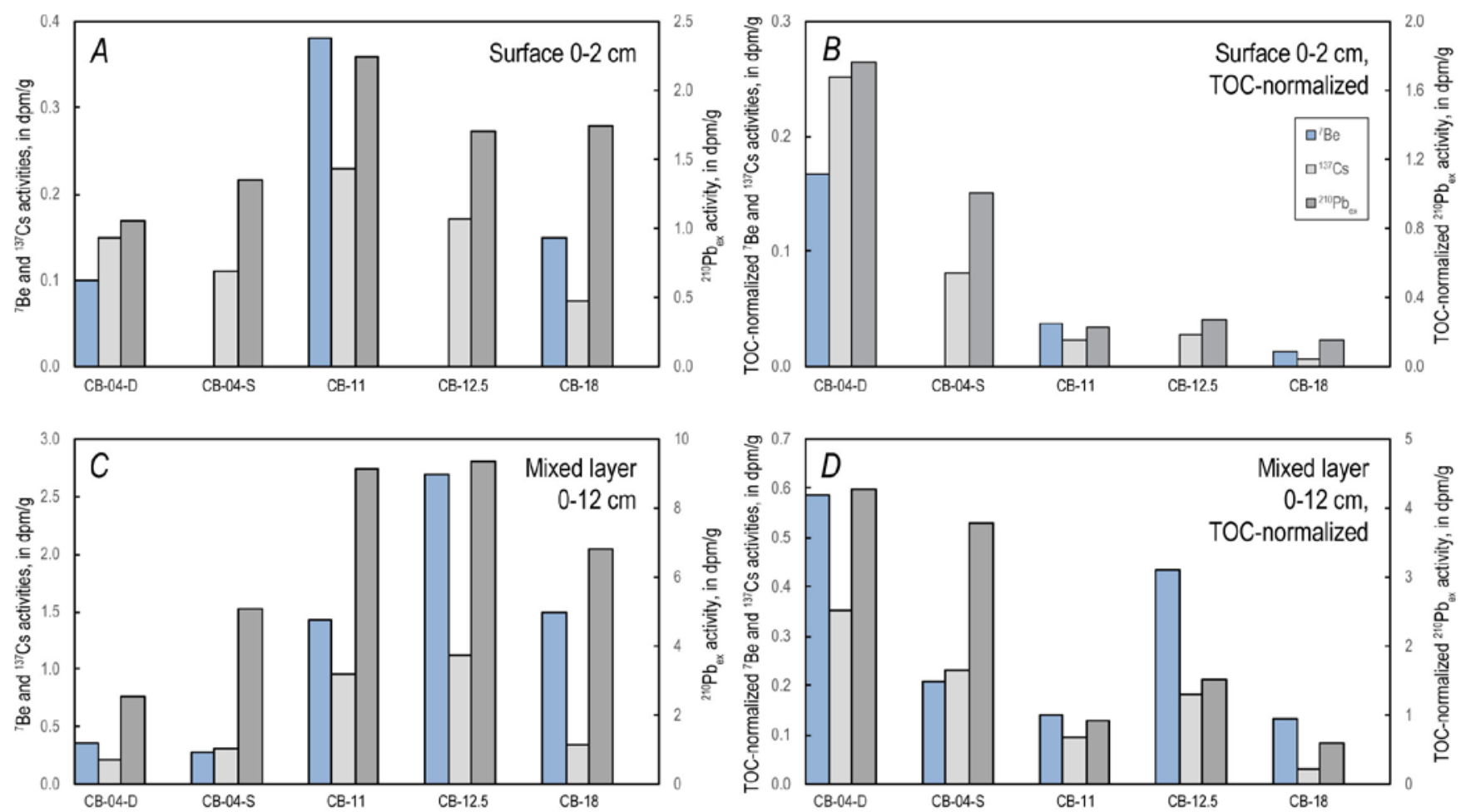

Figure 7. Graphs showing short-lived radionuclide activities in $(A)$ bulk surface layer sediment, $(B)$ surface layer sediment normalized by the total organic carbon content (TOC), (C) in the mixed layer, and $(D)$ in the mixed layer normalized by TOC at five sites in Commencement Bay (CB), Puget Sound, Washington. ${ }^{7} \mathrm{Be}$, beryllium-7; ${ }^{137} \mathrm{Cs}$, cesium-137; ${ }^{210} \mathrm{~Pb}_{\mathrm{ex}}$, excess lead-210; dpm/g, disintegrations per minute per gram of dry sediment; $\mathrm{cm}$, centimeter.

TOC-normalized radionuclide inventories in the mixed-layer were generally similar to surface patterns, having highest values at Browns Point (CB-04-D) and lowest values offshore of Puget Creek. The mixed layer at CB-12.5 (fig. 7D) had a high ${ }^{7}$ Be inventory and could reflect recent runoff from nearby Hylebos Creek.

\section{Elemental Composition of Nearshore Sediment}

Based on the $\mathrm{Ba} / \mathrm{Al}$ geochemical signature, nearshore fine sediment in Commencement Bay was more similar in composition to Puyallup River sediment than to Puget Lowland sediment. Assuming that the nearshore sediment sampled in this study was primarily a mixture of material from RIV and LOW, then the fraction of RIV in surface $(0-2 \mathrm{~cm})$ sediment in Commencement Bay calculated using a linear two end-member mixing equation ranged from 20-96 percent (fig. 8) and the median value was 77 percent. Surface sediment on the north shore of Commencement Bay (CB-03 to CB-12.5) generally had a greater fraction of riverborne sediment than that on the south shore of the bay (CB-14 to CB-23). 


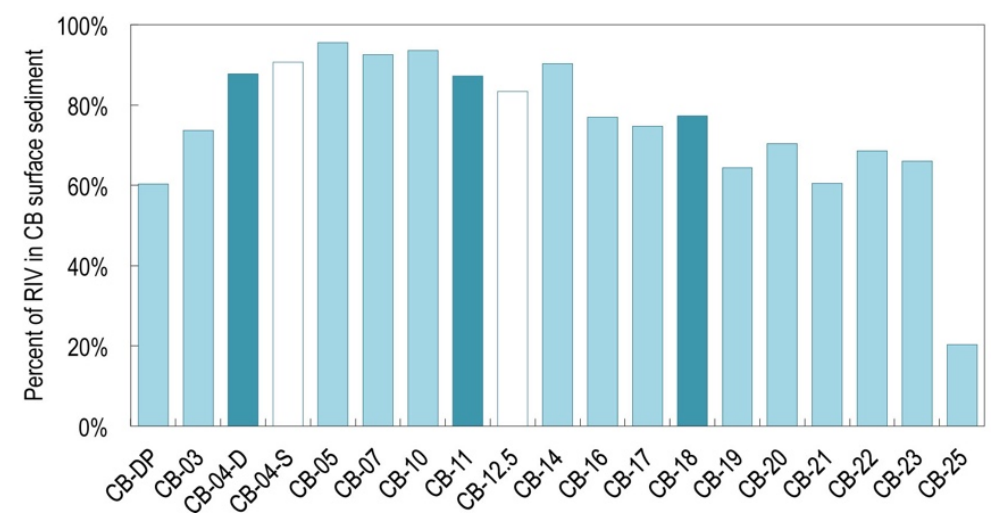

Figure 8. Plot showing the fraction of Puyallup and White River sediment (RIV) in surface fine sediment from Commencement Bay (CB), Puget Sound, Washington, on January 28, 2014, calculated from two endmember mixing. Dark blue columns show samples with measurable beryllium-7 ( $\left.{ }^{7} \mathrm{Be}\right)$; white columns show samples with no detectable ${ }^{7} \mathrm{Be}$. Samples shown by medium blue columns were not analyzed for radionuclides. Locations of sampling sites are shown in figure 2. \%, percent.

\section{Current-Use and Legacy Contaminants in Nearshore Sediment}

Nearshore sediment was sieved for contaminant analysis of the fine-sediment fraction $(<0.063 \mathrm{~mm})$ based on the low number and concentrations of chemicals detected on bulk river sediment, the increased number and concentrations of chemicals detected on suspended sediment, which has a finer grain-size distribution, and the knowledge that many organic chemicals preferentially sorb to finer rather than coarser sediment (Karickhoff and others, 1979). Sixty-one (of 157) organic chemicals were detected in winter nearshore fine sediment. This included 27 PAHs, 3 waste indicators, 7 hormones, and 24 halo-organic compounds. Table 3 lists the 36 compounds that were detected in more than one nearshore fine-sediment sample. PAHs were regularly detected in all three nearshore sediment samples; the lowest concentration for all but three individual PAHs was measured at CB-12.5 as compared to CB-04-S and CB-17. Among these three sites, CB-04-S and CB-12.5 were analyzed for short-lived radionuclides and contained no detectable ${ }^{7} \mathrm{Be}$ activity in the surface $0-2 \mathrm{~cm}$ layer, an indication that organic contaminants in surface sediment were deposited more than 5 months before sample collection in January 2014. Measurable ${ }^{7} \mathrm{Be}$ was found below the surface layer at CB-12.5 showing reworking of recently deposited sediment; however, contaminant assemblages were not measured in the corresponding subsurface layer. Four waste indicators and hormones were detected in all three nearshore samples, including $\beta$-sitosterol, indole, 3- $\beta$-coprostanol and cholesterol. A few legacy chlorinated pesticides were detected at low concentrations, including cis- and trans-chlordane, dieldrin, trans-nonachlor, and hexachlorobenzene. Twelve (of 18) PCB congeners were detected; the summed PCB concentration ranged from 1.83 to $2.77 \mu \mathrm{g} / \mathrm{kg}$, which when normalized to the median TOC content were well below the Washington State marine-sediment quality standard of $12 \mathrm{mg} / \mathrm{kg}$ organic carbon (Washington Department of Ecology, 2013). Seven (of 10) PBDE congeners were detected. CB-04-S had a summed PBDE concentration of $9.87 \mu \mathrm{g} / \mathrm{kg}$, representing 6 congeners. In contrast, the summed PBDE concentration was $1.2 \mu \mathrm{g} / \mathrm{kg}$ and 0.35 $\mu \mathrm{g} / \mathrm{kg}$ at CB-12.5 and CB-17, respectively, each representing the sum of 2 congeners. Washington State does not publish sediment quality standards for PBDEs. 
Table 3. Chemicals detected in more than one Commencement Bay, Puget Sound, Washington, finesediment sample.

[ $\mu \mathrm{g} / \mathrm{kg}$, microgram per kilogram dry weight; PBDEs, polybrominated diphenyl ethers; PCBs, polychlorinated biphenyls; E, estimated.]

\begin{tabular}{|c|c|c|}
\hline Chemical & $\begin{array}{c}\text { Maximum } \\
\text { detected } \\
\text { concentration } \\
(\mu \mathrm{g} / \mathrm{kg}) \\
\end{array}$ & $\begin{array}{l}\text { Number of } \\
\text { detects or } \\
\text { samples }\end{array}$ \\
\hline \multicolumn{3}{|c|}{ Polycyclic aromatic hydrocarbons } \\
\hline 1,6-dimethylnaphthalene & 53 & $3 / 3$ \\
\hline 1-methyl-9h-fluorene & 21 & $2 / 3$ \\
\hline 1-methylphenanthrene & 79.9 & $3 / 3$ \\
\hline 1-methylpyrene & 45.4 & $2 / 3$ \\
\hline 2,3,6-trimethylnaphthalene & 25.1 & $2 / 3$ \\
\hline 2,6-dimethylnaphthalene & 149 & $3 / 3$ \\
\hline 4,5-methylenephenanthrene & 74.2 & $3 / 3$ \\
\hline 9h-fluorene & 83.7 & $2 / 3$ \\
\hline Acenaphthene & 47.6 & $2 / 3$ \\
\hline Acenaphthylene & 57 & $2 / 3$ \\
\hline Anthracene & 145 & $3 / 3$ \\
\hline Anthraquinone & 134 & $3 / 3$ \\
\hline Benz[a]anthracene & 194 & $3 / 3$ \\
\hline Benzo[a]pyrene & 150 & $3 / 3$ \\
\hline Benzo[b]fluoranthene & E246 & $3 / 3$ \\
\hline Benzo[e]pyrene & 126 & $3 / 3$ \\
\hline Benzo[g,h,i]perylene & $\mathrm{E} 54.7$ & $3 / 3$ \\
\hline Benzo[k]fluoranthene & E85.7 & $3 / 3$ \\
\hline Carbazole & 36.8 & $3 / 3$ \\
\hline Chrysene & 269 & $3 / 3$ \\
\hline Fluoranthene & 748 & $3 / 3$ \\
\hline Indeno[1,2,3-cd]pyrene & E48.9 & $3 / 3$ \\
\hline Naphthalene & 259 & $3 / 3$ \\
\hline Perylene & 54.2 & $3 / 3$ \\
\hline Phenanthrene & 416 & $2 / 3$ \\
\hline Pyrene & 724 & $3 / 3$ \\
\hline \multicolumn{3}{|c|}{ Waste indicators and hormones } \\
\hline 3- $\beta$-coprostanol & E227 & $3 / 3$ \\
\hline 4-androstene-3,17-dione & 0.91 & $2 / 3$ \\
\hline Cholesterol & 2765 & $3 / 3$ \\
\hline Indole & 565 & $3 / 3$ \\
\hline$\beta$-sitosterol & E6580 & $3 / 3$ \\
\hline \multicolumn{3}{|c|}{ Halo-organic compounds } \\
\hline Chlordane, cis & 0.15 & $3 / 3$ \\
\hline Chlordane, trans & 0.13 & $2 / 3$ \\
\hline Hexachlorobenzene (HCB) & E2.2 & $3 / 3$ \\
\hline PBDEs (sum of 10) & 9.87 & $3 / 3$ \\
\hline PCBs (sum of 18) & 2.77 & $3 / 3$ \\
\hline
\end{tabular}


Nearshore fine-sediment contents of $\mathrm{As}, \mathrm{Cd}, \mathrm{Cu}, \mathrm{Pb}$, and $\mathrm{Zn}$ in Commencement Bay were enriched as much as ten-fold relative to geologic background levels in glacial clay (fig. 9), likely a legacy of ore smelting operations on the south shore of the bay and subsequent reuse of smelter slag as fill material along the south shore and in the industrial area at the head of the bay. Arsenic and $\mathrm{Pb}$ had maximum enrichment factors (EF) more than ten times higher than background; however, the median $\mathrm{EF}$ for As was approximately $1\left(\mathrm{EF}_{\mathrm{As}}=1.1\right.$, same as background), whereas that for $\mathrm{Pb}$ was $\mathrm{EF}_{\mathrm{Pb}}=2.4$. Arsenic was the only element whose content in Commencement Bay fine sediment exceeded the effects range median (ERM), the level determined by the National Oceanic and Atmospheric Administration (NOAA) at which adverse biological effects frequently occur in marine and estuarine sediment (Long and others, 1995), and this was found at only one site $\left(\mathrm{ERM}_{\mathrm{As}}=70 \mathrm{ppm} ; \mathrm{CB}-22_{\mathrm{As}}=87 \mathrm{ppm}\right)$. At no sites were the State of Washington's sedimentquality standards exceeded for anthropogenic elements in marine-sediment impact zones affected by discharges, which are higher than the NOAA ERMs for As (by 133 percent), Cu (by 144 percent), $\mathrm{Pb}$ (by 243 percent), and Zn (by 234 percent) and lower than the NOAA ERM for Cd (by 30 percent) (Washington Department of Ecology, 2013). The median sedimentary contents of anthropogenic metals and As measured in shallow areas of Commencement Bay in January 2014 on the $<0.063$-mm fine fraction were within 23 percent of the values at 30 stations surveyed by the Washington Department of Ecology in Commencement Bay in June 2014 (after those values were adjusted for the median fine-sediment content) (Weakland and others, 2016).

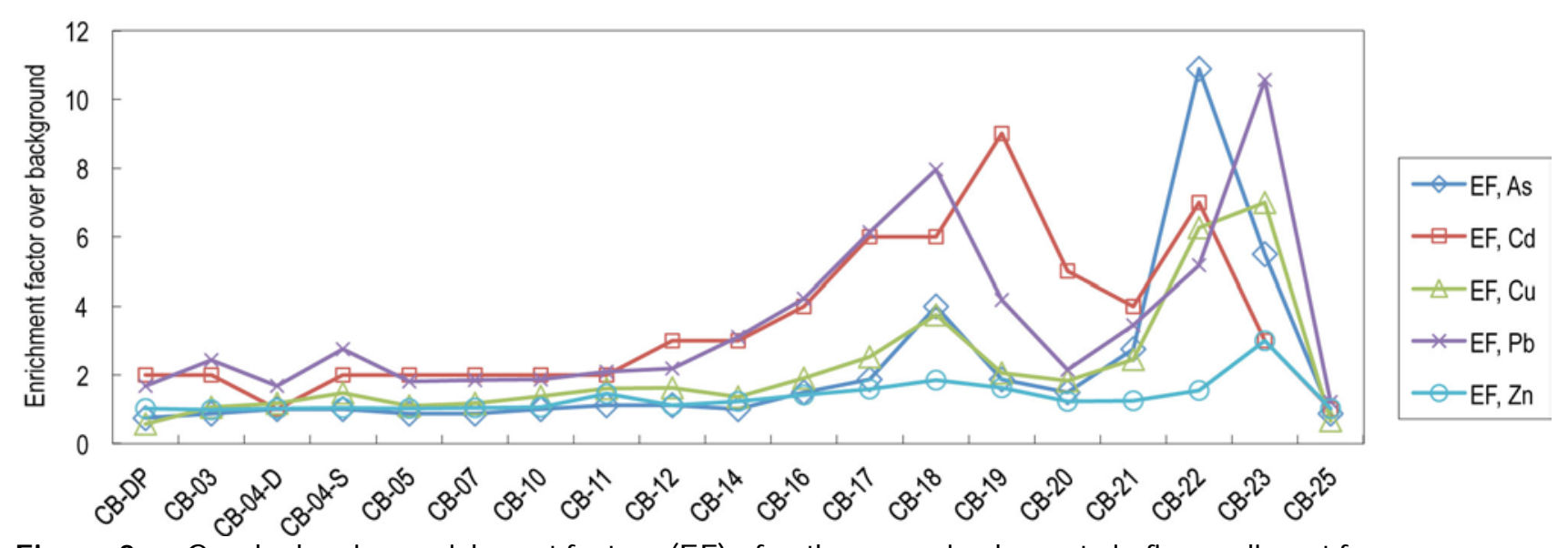

Figure 9. Graph showing enrichment factors (EF) of anthropogenic elements in fine sediment from Commencement Bay (CB), Puget Sound, Washington, over the geologic background in glacial deposits. As, arsenic; $\mathrm{Cd}$, cadmium; $\mathrm{Cu}$, copper; $\mathrm{Pb}$, lead; $\mathrm{Zn}$, zinc. Locations of sampling sites are shown in figure 2.

\section{Discussion}

The high proportion of river-derived sediment in the fine fraction of Commencement Bay nearshore sediment suggests that the Puyallup River is the dominant sediment source to the bay, a finding that is consistent with a deltaic environment. Spatial distributions of Al-normalized $\mathrm{Ba}$ contents of fine sediment show that the northeast shore of Commencement Bay received a higher proportion of fine sediment from the Puyallup River than the southwest shore and Dash Point (CB-DP), where glacial bluffs played a greater role as a secondary sediment source. 
The predominance of river-derived sediment in the nearshore region of Commencement Bay precluded event-scale runoff sourcing with composition-based geochemical signatures alone because riverine sediment entering the bay during a storm had only a slight compositional difference compared to preexisting sediment. In combination with ${ }^{7} \mathrm{Be}$ activities (TOCnormalized), it was determined that the sediment mixed layers at CB-04-D and CB-12.5 contained the most recently deposited riverborne fine sediment. A higher ${ }^{7} \mathrm{Be}$ inventory at the deeper site at Browns Point (CB-04-D, -16 m MLLW) compared to the shallower site (CB-04-S, $-8 \mathrm{~m}$ MLLW) could be indicative of downslope transport of riverborne sediment or a greater retention of fine sediment at deeper depths.

The elemental composition of sediment in summer runoff, which was not investigated in detail in this study, may allow discrimination of riverborne and nearshore sediment; however, because summer runoff largely originates in the forested upper watershed, it is not expected to be associated with contaminants of ecological concern. Indeed, few contaminants were detected in river suspended sediment collected in the summer, when the sediment primarily originates from glacial meltwater in the upper watershed. Most detections of river sediment-bound contaminants occurred in winter samples, suggesting that contaminants are introduced into the river during lowland runoff events.

Although a direct comparison between contaminant concentrations in river sediment and nearshore sediment is not possible because different particle size fractions were analyzed, a qualitative comparison suggests that nearshore sediment in Commencement Bay contains more contaminants, including persistent, legacy chemicals, than river sediment (fig. 10). For example, four PAHs at concentrations less than $25 \mu \mathrm{g} / \mathrm{kg}$ were detected in one river-bar sediment sample, and only during the winter. PAHs were not detected in two other winter river-bar and riverbank sediment samples or in $<2$-mm or fine-sediment samples collected during the summer. As many as 11 PAHs at concentrations less than $35 \mu \mathrm{g} / \mathrm{kg}$ were detected in river suspended sediment samples, which have a greater fraction of fine sediment than river-bar and riverbank sediment. In contrast, 27 PAHs were detected in winter nearshore fine sediment at concentrations as much as $750 \mu \mathrm{g} / \mathrm{kg}$. Based on a comparison of fine and $<2-\mathrm{mm}$ sediment from a nearby Puget Sound nearshore sediment sample (collected at Dockton in Quartermaster Harbor on Vashon Island, Puget Sound, Washington, August 20, 2013), the same suite of PAHs was present in both fine and $<2$-mm sediment. Fine sediment PAHs concentrations were similar to $<2$-mm sediment PAHs concentrations, with fine to $<2$-mm concentration ratios ranging from 0.4 to 1.5 (in exception, 2.8 for 2,6-dimethylnaphthalene). 

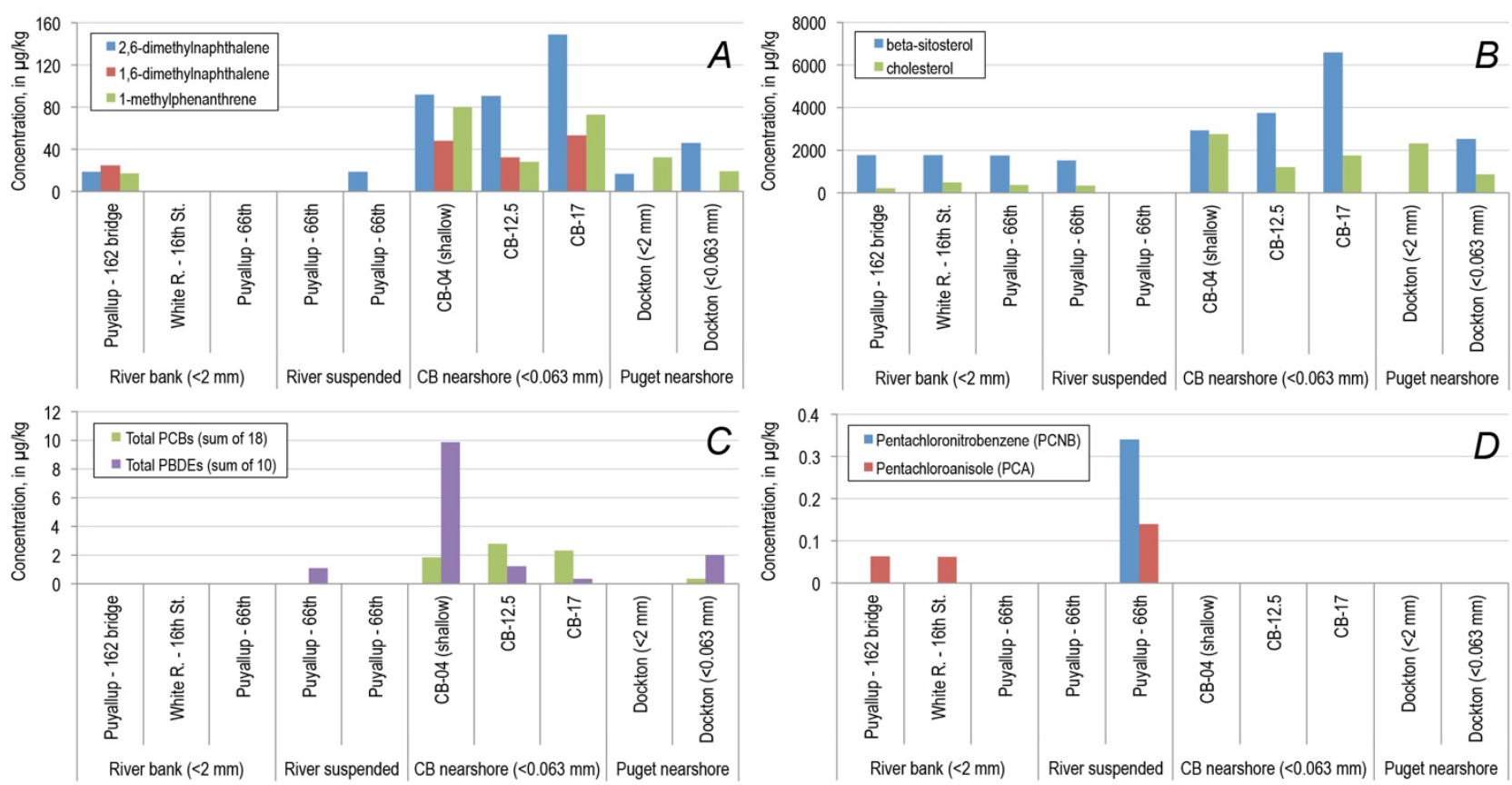

Figure 10. Graphs comparing contaminant concentrations in winter Puyallup River, Washington, sediment and nearshore sediment for $(A)$ three polycyclic aromatic hydrocarbons, $(B)$ two fecal sterols, $(C)$ two industrial chemicals, and $(D)$ two agricultural chemicals. A summer sample from a nearby Puget Sound nearshore location (Dockton) is also shown to relate chemical concentrations in <2-millimeter ( $\mathrm{mm}$ ) and $<0.063-\mathrm{mm}$ fractions. CB, Commencement Bay. dpm/g, disintegrations per minute per gram of dry sediment.

Similar to PAHs (fig. 10A), more contaminants at higher concentrations were measured in nearshore fine sediment than in river-bar, riverbank, or suspended sediment for fecal sterols (fig. 10B), legacy industrial chemicals (fig. 10C), and agricultural chemicals (fig. 10D). The higher occurrence of persistent, legacy compounds including PCBs, PBDEs, and chlorinated pesticides in the Commencement Bay nearshore than in the Puyallup River suggests that the nearshore sediment is impacted by other sources of contaminants in addition to contaminants transported by the Puyallup River, such as direct discharges of stormwater or wastewater to Commencement Bay and current and (or) historical human activities occurring directly in Commencement Bay.

Potential indicators of Puyallup River watershed overland run-off include PAHs, fecal indicators (cholesterol, $\beta$-sitosterol, indole, phenol), and pentachloroanisole. Of these, pentachloroanisole was unique to river sediment, as it was detected in both sediment from the Puyallup and White Rivers and not in nearshore sediment (fig. 10D). Pentachloroanisole is an environmental metabolite of pentachlorophenol (PCP), which is a general biocide, which has been used, for example, in agriculture and other industries for preserving wood. Other agricultural chemicals also may be indicators of recent sediment derived from the Puyallup River watershed, such as pentachloronitrobenzene (crop fungicide) and chlorinated pesticides like chlordane and chlorpyrifos, which were each detected in a single winter river suspendedsediment sample (not shown). Additional sampling of river suspended sediment over a range of flow, sediment, and seasonal conditions would aid in identifying additional indicator chemicals for the Puyallup River watershed. 


\section{Summary}

Understanding the fate, transport, and burial of riverborne sediment and sediment-bound contaminants in the coastal zone is an important step in assessing how these materials could affect coastal biogeochemical cycles and organisms. This USGS study combined river and marine sediment geochemistry and current-use and legacy contaminant analyses to identify riverborne sediment and associated contaminants at shoreline sites in Commencement Bay. Beaches in and near Commencement Bay are used by forage fish and other organisms that could be at risk of exposure to sediment-bound contaminants. The findings of the study are as follows:

- Winter fine sediment from the Puyallup and White Rivers was compositionally distinct from Puget Lowland glacial fine sediment based on ratios of immobile and relatively immobile elements- $\mathrm{Ba} / \mathrm{Al}, \mathrm{Ni} / \mathrm{Al}, \mathrm{Th} / \mathrm{Al}$, and $(\mathrm{La} / \mathrm{Yb})_{\mathrm{N}}$ ratios.

- Based on $\mathrm{Ba} / \mathrm{Al}$ ratios, surface sediment (0-2 cm) in Commencement Bay was predominantly composed of Puyallup River sediment compared to glacial bluff sediment. The northeast shore of the bay contained a larger proportion of Puyallup River sediment than did the southwest shore, where glacial bluffs were a larger secondary sediment source.

- $\quad{ }^{7}$ Be activities showed that sediment from the Puyallup River was present in the nearshore sediment mixed layer at all five sites where it was measured and that the highest TOCnormalized activities (most recent deposition) occurred at -16 m depth (MLLW) offshore of Browns Point and west of the mouth of Hylebos Creek.

- Contaminants associated with Puyallup River sediment primarily originated from runoff from the Puget Lowlands in winter rather than the upper watershed where glacial meltwater is the main component of flow in summer.

- Nearshore sediment in Commencement Bay is impacted by other sources of contaminants in addition to those carried by Puyallup River sediment, such as legacy embayment contamination from past activities, such as railroad and sawmill operations and ore smelting, and current urban stormwater.

\section{Acknowledgments}

James Foreman (USGS), Rich Sheibley (USGS), Cordell Johnson (USGS), and Greg Justin (USGS, retired) assisted with field sampling; Cordell Johnson measured short-lived radionuclides. Leticia Hallas (USGS) processed samples for geochemical analyses. The USGS Washington Water Science Center provided field and lab support. Christopher Conaway and Margaret Dutch provided suggestions that improved the manuscript. The USGS Coastal and Marine Geology Program, and the Effects of Urbanization Task of the Multidisciplinary Coastal Habitats in Puget Sound Project funded this work.

\section{References Cited}

Briggs, P.H., and Meier, A.L., 2002, The determination of forty-two elements in geological materials by inductively coupled plasma-mass spectrometry, chap. I of, Taggart, J.E., ed., Analytical methods for chemical analysis of geologic and other materials: U.S. Geological Survey USGS Open-File Report 02-223, 20 p., accessed August 25, 2017, at https://pubs.usgs.gov/of/2002/ofr-02-0223/. 
Burkhardt, M.R., Zaugg, S.D., Smith, S.G., and ReVello, R.C., 2006, Determination of wastewater compounds in sediment and soil by pressurized solvent extraction, solid-phase extraction, and capillary-column gas chromatography/mass spectrometry: U.S. Geological Survey Techniques and Methods, book 5, chap. B2, 40 p., accessed August 25, 2017, at https://pubs.usgs.gov/tm/2006/tm5b2/.

Cannon, G.A., and Grigsby, M.W., 1982, Observations of currents and water properties in Commencement Bay: Boulder, Colo., National Oceanic and Atmospheric Administration Technical Memorandum OMPA-22, 37 p., accessed August 25, 2017, at https://docs.lib.noaa.gov/noaa_documents/NOS/OMPA/TM_NOS_OMPA/nos_ompa_22.pdf.

Carpenter, R., Peterson, M.L., and Bennett, J.T., 1985, ${ }^{210} \mathrm{~Pb}$-derived sediment accumulation and mixing rates for greater Puget Sound region: Marine Geology, v. 64, p. 291-312.

Condie, K.C., and Swenson, D.H., 1973, Compositional variation in three Cascade stratovolcanoes-Jefferson, Rainier, and Shasta: Bulletin Volcanologique, v. 37, no. 2, p. 205230.

Conn, K.E., Dinicola, R.S., Black, R.W., Cox, S.E., Sheibley, R.W., Foreman, J.R., Senter, C.A., and Peterson, N.T., 2016, Continuous-flow centrifugation to collect suspended sediment for chemical analysis: U.S. Geological Survey Techniques and Methods, book 1, chap. D6, 31 p. plus appendixes, accessed August 25, 2017, at https://doi.org/10.3133/tm1D6.

Crawford, M.L., Crawford, W.A., and Lindline, J., 2005, 105 million years of igneous activity, Wrangell, Alaska, to Prince Rupert, British Columbia: Canadian Journal of Earth Sciences, v. 42, p. 109-116.

Czuba, J.A., Czuba, C.R., Magirl, C.S., and Voss, F.D., 2010, Channel-conveyance capacity, channel change, and sediment transport in the lower Puyallup, White, and Carbon Rivers, western Washington: U.S. Geological Survey Scientific Investigations Report 2010-5240, 104 p., accessed August 25, 2017, at https://pubs.usgs.gov/sir/2010/5240/.

Czuba, J.A., Magirl, C.S., Czuba, C.R., Curran, C.A., Johnson, K.H., Olsen, T.D., Kimball, H.K., and Gish, C.C., 2012, Geomorphic analysis of the river response to sedimentation downstream of Mount Rainier, Washington: U.S. Geological Survey Open-File Report 20121242, 134 p., accessed August 25, 2017, at https://pubs.usgs.gov/of/2012/1242/.

Davis, A., de Curnou, P., and Eary, L.E., 1997, Discriminating between sources of arsenic in the sediments of a tidal waterway, Tacoma, Washington: Environmental Science and Technology, v. 31, p. 1985-1991.

Ebbesmeyer, C.C., Coomes, C.A., Cox, J.M., Baker, E.T., Smyth, C.S., and Barnes, C.A., 1986, Dynamics of Commencement Bay and approaches: Rockville, Md., National Oceanic and Atmospheric Administration Technical Memorandum NOS OMA 24, 79 p., accessed August 25, 2017, at https://docs.lib.noaa.gov/noaa_documents/NOS/OMA/TM_NOS_OMA/nos_oma_24.PDF.

Fernandez, J.M., Ouillon, S., Chevillon, C., Douillet, P., Fichez, R., and Le Gendre, R., 2006, A combined modelling and geochemical study of the fate of terrigenous inputs from mixed natural and mining sources in a coral reef lagoon (New Caledonia): Marine Pollution Bulletin, v. 52, p. 320-331.

Fiske, R.S., Hopson, C.A., and Waters, A.C., 1964, Geologic map and section of Mount Rainier National Park, Washington: U.S. Geological Survey Miscellaneous Geological Investigations Map I-432, 1 p. [Also available at https://pubs.er.usgs.gov/publication/i432.]

Folk, R.L., and Ward, W.C., 1957, Brazos River bar-A study in the significance of grain size parameters: Journal of Sedimentary Petrology, v. 27, p. 3-26. 
Foreman, W.T., Gray, J.L., ReVello, R.C., Lindley, C.E., Losche, S.A., and Barber, L.B., 2012, Determination of steroid hormones and related compounds in filtered and unfiltered water by solid-phase extraction, derivatization, and gas chromatography with tandem mass spectrometry: U.S. Geological Survey Techniques and Methods, book 5, chap. B9, 118 p., accessed August 25, 2017, at https://pubs.usgs.gov/tm/5b9/.

Garcia-Agudo, E., 1998, Global distribution of ${ }^{137} \mathrm{Cs}$ inputs for soil erosion and sedimentation studies, in Proceedings of a consultants meeting on the use of ${ }^{137} \mathrm{Cs}$ in the study of soil erosion and sedimentation, 13-16 November 1995, Vienna, Austria, International Atomic Energy Agency, p. 117-121.

Jones, M.A., 1999, Geologic framework of the Puget Sound aquifer system, Washington and British Columbia: U.S. Geological Survey Professional Paper 1424-C, 31 p., accessed August 25, 2017, at https://pubs.er.usgs.gov/publication/pp1424C.

Karickhoff, S.W., Brown, D.S., and Scott, T.A., 1979, Sorption of hydrophobic pollutants on natural sediments: Water Research, v. 13, no. 3, p. 241-248.

Long, E.R., MacDonald, D.D., Smith, S.L., and Calder, F.D., 1995, Incidence of adverse biological effects within ranges of chemical concentrations in marine and estuarine sediments: Environmental Management, v. 19, no. 1, p. 81-97.

Matisoff, G., Bonniwell, E.C., and Whiting, P.J., 2002, Soil erosion and sediment sources in an Ohio watershed using beryllium-7, cesium-137, and lead-210: Journal of Environmental Quality, v. 31, no. 1, p. 54-61.

McLennan, S.M., 1989, Rare earth elements in sedimentary rocks: influence of provenance and sedimentary processes, in Lipin, B.R., and McKay, G.A., eds., Geochemistry and mineralogy of rare earth elements: Washington, D.C., The Mineralogical Society of America, p. 169-200. McLennan, S.M., Taylor, S.R., McCulloch, M.T., and Maynard, J.B., 1990, Geochemical and $\mathrm{Nd}-\mathrm{Sr}$ isotopic compositions of deep-sea turbidies: crustal evolution and plate tectonic associations: Geochimica et Cosmochimica Acta, v. 54, p. 2015-2050.

Mee, L., 2012, Between the devil and the deep blue sea: the coastal zone in an era of globalization: Estuarine, Coastal and Shelf Science, v. 96, p. 1-8.

Prego, R., Caetano, M., Bernárdez, P., Brito, P., Ospina-Alvarez, N., and Vale, C., 2012, Rare earth elements in coastal sediment of the northern Galician shelf-Influence of geologic features: Continental Shelf Research, v. 35, p. 75-85.

Prego, R., Caetano, M., Vale, C., and Marmolejo-RodrÍguez, J., 2009, Rare earth elements in sediments of the Vigo Ria, NW Iberian Peninsula: Continental Shelf Research, v. 29, p. 896902.

Schwarzenbach, R.P., Escher, B.I., Fenner, K., Hofstetter, T.B., Johnson, C.A., von Gunten, U., and Wehrli, B., 2006, The challenge of micropollutants in aquatic systems: Science, v. 313, p. 1072-1077.

Sisson, T.W., and Vallance, J.W., 2009, Frequent eruptions of Mount Rainier over the last 2,600 years: Bulletin of Volcanology, v. 71, p. 595-618.

Smith, D.R., and Leeman, W.P., 1993, The origin of Mount St. Helens andesites: Journal of Volcanology and Geothermal Research, v. 55, p. 271-303.

Sommerfield, C.A., Nittrouer, C.A., and Alexander, C.R., $1999,{ }^{7}$ Be as a tracer of flood sedimentation on the northern California continental margin: Continental Shelf Research, v. 19, no. 3, p. 335-361.

Wagner, R.J., Moran, P.W., Zaugg, S.D., Sevigny, J.M., and Pope, J.M., 2014, Contaminants of emerging concern in the lower Stillaguamish River Basin, Washington, 2008-11: U.S. 
Geological Survey Open-File Report 2014-1028, 14 p., accessed August 25, 2017, at https://doi.org/10.3133/ofr20141028.

Washington Department of Ecology, 2013, Sediment management standards, chapter 173-204

WAC: Olympia, Wash., Washington Department of Ecology publication no. 13-09-055, 135 p., accessed August 25, 2017, at https://fortress.wa.gov/ecy/publications/documents/1309055.pdf.

Washington Office of Financial Management, 2016, State of Washington 2016 Population Trends: Washington Office of Financial Management, Forecasting and Research Division, 49 p., accessed August 25, 2017, at http://www.ofm.wa.gov/pop/april1/poptrends.pdf.

Weakland, S.V., Partridge, V., and Dutch, M., 2016, Urban bays monitoring 2014—Sediment quality in Commencement Bay, Tacoma, WA: Olympia, Wash., Washington State Department of Ecology 16-03-011, 8 p. plus appendixes.

Zaugg, S.D., Burkhardt, M.R., Burbank, T.L., Olsen, M.C., Iverson, J.L., and Schroeder, M.P., 2006, Determination of semivolatile organic compounds and polycyclic aromatic hydrocarbons in solids by gas chromatography/mass spectrometry: U.S. Geological Survey Techniques and Methods, book 5, chap. B3, 44 p., accessed August 25, 2017, at https://pubs.usgs.gov/tm/2006/tm5b3/. 


\section{Appendix 1. Contents of Anthropogenic Metals, Grain-Size Parameters, and Organic Carbon Contents of Nearshore Fine Sediment Collected in Commencement Bay, Washington, January 28, 2014}

[Sediment-quality guidelines (ERL, effects range low; ERM, effects range median) and the geologic background (BKGD) are shown for comparison. As, arsenic; Cd, cadmium; Cu, copper; Pb, lead; Zn, zinc; D50, median grain size; OC, organic carbon; $\mu \mathrm{g} / \mathrm{g}$, micrograms per gram; \%, percent; mm, millimeter]

\begin{tabular}{|c|c|c|c|c|c|c|c|c|c|c|c|c|}
\hline Sample no. & $\begin{array}{c}\text { As } \\
(\mu \mathrm{g} / \mathrm{g})\end{array}$ & $\begin{array}{c}\mathrm{Cd} \\
(\mu \mathrm{g} / \mathrm{g})\end{array}$ & $\begin{array}{c}\mathrm{Cu} \\
(\mu \mathrm{g} / \mathrm{g})\end{array}$ & $\begin{array}{c}\mathrm{Pb} \\
(\mu \mathrm{g} / \mathrm{g})\end{array}$ & $\begin{array}{c}\mathrm{Zn} \\
(\mu \mathrm{g} / \mathrm{g})\end{array}$ & $\begin{array}{c}\text { Gravel } \\
\text { (\%) }\end{array}$ & $\begin{array}{c}\text { Sand } \\
\text { (\%) }\end{array}$ & $\begin{array}{l}\text { Silt } \\
\text { (\%) }\end{array}$ & $\begin{array}{l}\text { Clay } \\
\text { (\%) }\end{array}$ & $\begin{array}{l}\text { Mud } \\
\text { (\%) }\end{array}$ & $\begin{array}{c}\text { D50 } \\
(\mathrm{mm})\end{array}$ & $\begin{array}{l}O C \\
\text { (\%) }\end{array}$ \\
\hline CB-03 & 7 & 0.2 & 28 & 19 & 73 & 1.9 & 92.6 & 3.0 & 2.5 & 5.4 & 0.285 & 0.2 \\
\hline CB-04-D & 8 & 0.1 & 31 & 13 & 76 & 2.9 & 65.3 & 20.4 & 11.4 & 31.8 & 0.140 & 1.3 \\
\hline CB-04-S & 8 & 0.2 & 38 & 22 & 77 & 7.0 & 74.6 & 11.8 & 6.6 & 18.4 & 0.226 & 0.6 \\
\hline CB-05 & 7 & 0.2 & 28 & 14 & 76 & 0.4 & 89.3 & 6.2 & 4.1 & 10.3 & 0.271 & 0.2 \\
\hline CB-07 & 7 & 0.2 & 30 & 14 & 77 & 2.5 & 73.3 & 16.1 & 8.1 & 24.2 & 0.185 & 0.6 \\
\hline CB-10 & 8 & 0.2 & 36 & 15 & 79 & 7.2 & 63.9 & 18.6 & 10.2 & 28.9 & 0.247 & 0.5 \\
\hline CB-11 & 9 & 0.2 & 42 & 16 & 107 & 1.7 & 7.3 & 58.7 & 32.4 & 91.1 & 0.009 & 10.1 \\
\hline CB-12 & 9 & 0.3 & 42 & 17 & 82 & 0.2 & 9.8 & 61.0 & 29.0 & 90.1 & 0.011 & 6.2 \\
\hline CB-14 & 8 & 0.3 & 36 & 24 & 91 & 21.7 & 56.8 & 15.6 & 5.9 & 21.6 & 0.338 & 1.5 \\
\hline CB-16 & 12 & 0.4 & 50 & 33 & 105 & 24.5 & 51.3 & 16.8 & 7.4 & 24.2 & 0.289 & 3.1 \\
\hline CB-17 & 15 & 0.6 & 66 & 48 & 117 & 0.0 & 86.7 & 9.3 & 4.0 & 13.3 & 0.169 & 2.7 \\
\hline CB-18 & 32 & 0.6 & 97 & 62 & 137 & 0.0 & 62.0 & 27.1 & 10.9 & 38.0 & 0.090 & 11.5 \\
\hline CB-19 & 15 & 0.9 & 54 & 33 & 120 & 0.2 & 85.2 & 9.8 & 4.8 & 14.7 & 0.265 & 2.9 \\
\hline CB-20 & 12 & 0.5 & 48 & 17 & 91 & 0.0 & 93.4 & 4.3 & 2.3 & 6.6 & 0.227 & 0.2 \\
\hline CB-21 & 22 & 0.4 & 64 & 27 & 92 & 0.0 & 93.2 & 4.6 & 2.3 & 6.8 & 0.184 & 0.3 \\
\hline CB-22 & 87 & 0.7 & 163 & 40 & 114 & 0.0 & 82.4 & 12.4 & 5.3 & 17.6 & 0.133 & 8.4 \\
\hline CB-23 & 44 & 0.3 & 182 & 82 & 222 & 0.5 & 96.0 & 1.9 & 1.6 & 3.5 & 0.284 & 0.2 \\
\hline CB-25 & 7 & 0.1 & 17 & 10 & 76 & 0.9 & 93.2 & 4.3 & 1.6 & 5.9 & 0.493 & 0.1 \\
\hline CB-DP & 6 & 0.2 & 15 & 13 & 76 & 0.0 & 90.8 & 6.5 & 2.7 & 9.2 & 0.164 & 0.6 \\
\hline \multicolumn{13}{|c|}{ Sediment-quality guidelines and geologic background } \\
\hline ERL $^{1}$ & 8.2 & 1.2 & 34 & 46.7 & 150 & & & & & & & \\
\hline $\mathrm{ERM}^{2}$ & 70 & 9.6 & 270 & 218 & 410 & & & & & & & \\
\hline $\mathrm{BKGD}^{3}$ & 8 & 0.1 & 26 & 7.8 & 74 & & & & & & & \\
\hline $\begin{array}{c}\text { Number of } \\
\text { samples } \\
>\text { ERL }\end{array}$ & 10 & 0 & 13 & 3 & 1 & & & & & & & \\
\hline $\begin{array}{c}\text { Number of } \\
\text { samples } \\
\text { >ERM }\end{array}$ & 1 & 0 & 0 & 0 & 0 & & & & & & & \\
\hline
\end{tabular}

${ }^{1}$ ERL values from Long and others (1995).

${ }^{2}$ ERM values from Long and others (1995).

${ }^{3}$ Values from Point Defiance, Tacoma, Washington, glacial clay were used for the geologic background. 


\section{Appendix 2. Contents of Aluminum, Barium, and Trace Elements in Fine Sediment Collected from the Puyallup Watershed, Commencement Bay, and Point Bolin, Washington}

[PU, Puyallup River; WH, White River; CB, Commencement Bay; PB, Point Bolin; Al, aluminum; Ba, barium; Ni, nickel; Th, thorium; $(\mathrm{La})_{\mathrm{N}}$, North American shale composite normalized lanthanum; $(\mathrm{Yb})_{\mathrm{N}}$, North American shale composite normalized ytterbium; \%, percent; $\mu \mathrm{g} / \mathrm{g}$, micrograms per gram]

\begin{tabular}{|c|c|c|c|c|c|c|c|c|}
\hline Sample type & Sample no. & $\begin{array}{c}\text { Date } \\
\text { collected }\end{array}$ & $\begin{array}{c}\mathrm{Al} \\
(\%)\end{array}$ & $\begin{array}{c}\mathrm{Ba} \\
(\mu \mathrm{g} / \mathrm{g})\end{array}$ & $\begin{array}{c}\mathrm{Ni} \\
(\mu \mathrm{g} / \mathrm{g})\end{array}$ & $\begin{array}{c}\text { Th } \\
(\mu \mathrm{g} / \mathrm{g})\end{array}$ & $(\mathrm{La})_{\mathrm{N}}$ & $(Y b)_{N}$ \\
\hline River & PU13-01 & $1 / 20 / 13$ & 8.27 & 340 & 31.7 & 4.7 & 0.64 & 0.55 \\
\hline River & PU13-02 & $1 / 20 / 13$ & 7.73 & 339 & 33.0 & 4.7 & 0.68 & 0.58 \\
\hline River & PU13-03 & $1 / 20 / 13$ & 8.04 & 335 & 34.4 & 4.7 & 0.67 & 0.52 \\
\hline River & PU13-05 & $1 / 21 / 13$ & 7.89 & 315 & 39.6 & 5.2 & 0.61 & 0.61 \\
\hline River & PU13-06 & $1 / 21 / 13$ & 8.02 & 304 & 44.7 & 4.4 & 0.57 & 0.55 \\
\hline River & PU14-01 & $1 / 29 / 14$ & 9.42 & 376 & 27.5 & 4.5 & 0.54 & 0.39 \\
\hline River & PU14-02 & $1 / 29 / 14$ & 8.91 & 364 & 34.9 & 4.9 & 0.63 & 0.48 \\
\hline River & PU14-03 & $1 / 29 / 14$ & 8.17 & 331 & 35.4 & 4.6 & 0.61 & 0.55 \\
\hline River & WH13-01 & $1 / 21 / 13$ & 8.77 & 400 & 16.3 & 5.6 & 0.63 & 0.55 \\
\hline River & WH13-02 & $1 / 21 / 13$ & 8.56 & 367 & 23.4 & 4.9 & 0.63 & 0.61 \\
\hline River & WH14-01 & $1 / 29 / 14$ & 8.28 & 341 & 27.1 & 4.1 & 0.52 & 0.48 \\
\hline River & WH14-02 & $1 / 29 / 14$ & 8.99 & 372 & 17.9 & 4.5 & 0.55 & 0.39 \\
\hline River & WH14-03 & 1/29/14 & 9.24 & 384 & 19.6 & 4.6 & 0.55 & 0.45 \\
\hline Nearshore & CB-03 & $1 / 28 / 14$ & 7.61 & 362 & 24.6 & 4.6 & 0.55 & 0.45 \\
\hline Nearshore & CB-04-D & $1 / 28 / 14$ & 8.90 & 394 & 24.1 & 5.1 & 0.58 & 0.45 \\
\hline Nearshore & CB-04-S & $1 / 28 / 14$ & 8.65 & 377 & 24.3 & 5.0 & 0.59 & 0.48 \\
\hline Nearshore & CB-05 & $1 / 28 / 14$ & 8.95 & 380 & 27.0 & 4.8 & 0.56 & 0.45 \\
\hline Nearshore & CB-07 & $1 / 28 / 14$ & 8.85 & 382 & 22.7 & 4.9 & 0.57 & 0.45 \\
\hline Nearshore & CB-10 & $1 / 28 / 14$ & 8.76 & 376 & 21.8 & 4.9 & 0.60 & 0.48 \\
\hline Nearshore & CB-11 & $1 / 28 / 14$ & 8.38 & 372 & 21.5 & 4.7 & 0.57 & 0.42 \\
\hline Nearshore & CB-12.5 & $1 / 28 / 14$ & 8.17 & 370 & 22.5 & 5.0 & 0.67 & 0.52 \\
\hline Nearshore & CB-14 & $1 / 28 / 14$ & 8.77 & 383 & 24.1 & 4.6 & 0.55 & 0.42 \\
\hline Nearshore & CB-16 & $1 / 28 / 14$ & 8.08 & 378 & 26.0 & 4.6 & 0.55 & 0.45 \\
\hline Nearshore & CB-17 & $1 / 28 / 14$ & 7.82 & 370 & 32.9 & 4.6 & 0.60 & 0.52 \\
\hline Nearshore & CB-18 & $1 / 28 / 14$ & 7.90 & 369 & 30.2 & 4.4 & 0.56 & 0.55 \\
\hline Nearshore & CB-19 & $1 / 28 / 14$ & 7.44 & 370 & 30.9 & 4.1 & 0.49 & 0.45 \\
\hline Nearshore & CB-20 & $1 / 28 / 14$ & 7.14 & 345 & 41.9 & 4.7 & 0.60 & 0.71 \\
\hline Nearshore & CB-21 & $1 / 28 / 14$ & 7.01 & 355 & 41.8 & 4.1 & 0.55 & 0.58 \\
\hline Nearshore & CB-22 & $1 / 28 / 14$ & 7.20 & 351 & 30.1 & 3.9 & 0.50 & 0.48 \\
\hline Nearshore & CB-23 & $1 / 28 / 14$ & 7.42 & 366 & 32.7 & 4.0 & 0.53 & 0.45 \\
\hline Nearshore & CB-25 & $1 / 28 / 14$ & 7.55 & 453 & 57.0 & 3.5 & 0.45 & 0.58 \\
\hline Nearshore & CB-DP & $1 / 28 / 14$ & 6.91 & 350 & 46.9 & 4.7 & 0.53 & 0.61 \\
\hline Glacial bluff & PB13-01 & $6 / 25 / 13$ & 8.84 & 581 & 61.2 & 4.2 & 0.47 & 0.61 \\
\hline Glacial bluff & PB13-10 & $6 / 25 / 13$ & 7.06 & 450 & 45.6 & 2.7 & 0.52 & 0.68 \\
\hline Glacial bluff & PB13-11 & $6 / 25 / 13$ & 6.78 & 429 & 42.9 & 2.4 & 0.49 & 0.55 \\
\hline Glacial clay & Point Defiance & 8/19/13 & 7.60 & 503 & 58.1 & 3.3 & 0.45 & 0.61 \\
\hline
\end{tabular}




\section{Appendix 3. Radionuclide Activities in Sediment Cores Collected in Commencement Bay, Washington, January 28, 2014}

[CB, Commencement Bay; ${ }^{7} \mathrm{Be}$, beryllium-7; ${ }^{137} \mathrm{Cs}$, cesium-137; ${ }^{210} \mathrm{~Pb}$, lead-210; ${ }^{226} \mathrm{Ra}$, radium-226; ${ }^{210} \mathrm{~Pb}$ ex , excess lead-210; cm, centimeters; dpm/g, disintegrations per minute per gram]

\begin{tabular}{lcccccc}
\hline Site no. & $\begin{array}{c}\text { Depth interval } \\
\text { (cm) }\end{array}$ & $\begin{array}{c}{ }^{7} \mathrm{Be} \\
\text { (dpm/g) }\end{array}$ & $\begin{array}{c}{ }^{137} \mathrm{Cs} \\
\text { (dpm/g) }\end{array}$ & $\begin{array}{c}{ }^{210} \mathrm{~Pb} \\
\text { (dpm/g) }\end{array}$ & $\begin{array}{c}{ }^{226} \mathrm{Ra} \\
\text { (dpm/g) }\end{array}$ & $\begin{array}{c}{ }^{210} \mathrm{~Pb}_{\text {ex }} \\
\text { (dpm/g) }\end{array}$ \\
\hline CB-04-S & $0-2$ & 0.1 & 0.2 & 1.8 & 0.8 & 1.1 \\
CB-04-S & $2-4$ & 0.3 & 0.1 & 2.4 & 0.9 & 1.5 \\
CB-04-S & $4-6$ & 0.0 & 0.1 & 2.2 & 0.9 & 1.4 \\
CB-04-S & $6-8$ & 0.0 & 0.1 & 2.1 & 0.9 & 1.3 \\
CB-04-D & $0-2$ & 0.3 & 0.0 & 2.0 & 0.9 & 1.2 \\
CB-04-D & $2-4$ & 0.0 & 0.1 & 2.3 & 1.0 & 1.4 \\
CB-11 & $0-2$ & 0.4 & 0.2 & 3.6 & 1.4 & 2.3 \\
CB-11 & $2-4$ & 0.4 & 0.2 & 3.4 & 1.3 & 2.1 \\
CB-11 & $4-6$ & 0.6 & 0.4 & 3.6 & 1.1 & 2.5 \\
CB-11 & $6-8$ & 0.0 & 0.1 & 3.4 & 1.1 & 2.3 \\
CB-12.5 & $0-2$ & 0.0 & 0.2 & 2.8 & 1.1 & 1.7 \\
CB-12.5 & $2-4$ & 0.0 & 0.1 & 3.1 & 1.4 & 1.7 \\
CB-12.5 & $4-6$ & 2.7 & 0.2 & 2.5 & 1.1 & 1.4 \\
CB-12.5 & $6-8$ & 0.0 & 0.2 & 2.4 & 1.6 & 0.8 \\
CB-12.5 & $8-10$ & 0.0 & 0.2 & 2.9 & 0.8 & 2.2 \\
CB-12.5 & $10-12$ & 0.0 & 0.3 & 2.8 & 1.2 & 1.6 \\
CB-18 & $0-2$ & 0.2 & 0.1 & 2.7 & 0.9 & 1.8 \\
CB-18 & $2-4$ & 0.6 & 0.1 & 2.7 & 0.8 & 1.9 \\
CB-18 & $4-6$ & 0.4 & 0.2 & 2.9 & 0.7 & 2.3 \\
CB-18 & $6-8$ & 0.4 & 0.0 & 1.6 & 0.7 & 0.9 \\
\hline
\end{tabular}




\section{Appendix 4. Chemical Parameters Analyzed by the U.S. Geological Survey National Water Quality Laboratory in Sediment Collected from the Puyallup and White Rivers and Commencement Bay, Washington}

\begin{tabular}{|c|c|}
\hline Parameter & Parameter code \\
\hline \multicolumn{2}{|c|}{ Polycyclic aromatic hydrocarbons by schedule 5506} \\
\hline 2,6-dimethylnaphthalene ${ }^{1}$ & 63167 \\
\hline anthracene $^{1}$ & 63180 \\
\hline anthraquinone $^{1}$ & 63181 \\
\hline benzo[a]pyrene $^{1}$ & 63183 \\
\hline bis(2-ethylhexyl) phthalate ${ }^{1}$ & 63187 \\
\hline carbazole $^{1}$ & 63194 \\
\hline diethyl phthalate ${ }^{1}$ & 63202 \\
\hline fluoranthene ${ }^{1}$ & 63208 \\
\hline naphthalene $^{1}$ & 63220 \\
\hline phenanthrene $^{1}$ & 63224 \\
\hline pyrene $^{1}$ & 63227 \\
\hline benz[a]anthracene & 63610 \\
\hline hexachlorobenzene ${ }^{2}$ & 63631 \\
\hline pentachloronitrobenzene $^{2}$ & 63650 \\
\hline 1,2,4-trichlorobenzene & 64095 \\
\hline 1,2-dimethylnaphthalene & 64097 \\
\hline 1,6-dimethylnaphthalene & 64099 \\
\hline 1-methyl-9h-fluorene & 64100 \\
\hline 1-methylphenanthrene & 64101 \\
\hline 1-methylpyrene & 64102 \\
\hline 2,3,6-trimethylnaphthalene & 64103 \\
\hline 2-ethylnaphthalene & 64104 \\
\hline 2-methylanthracene & 64105 \\
\hline 4,5-methylenephenanthrene & 64106 \\
\hline 9h-fluorene & 64107 \\
\hline acenaphthene & 64108 \\
\hline acenaphthylene & 64109 \\
\hline benzo[b]fluoranthene & 64111 \\
\hline benzo[e]pyrene & 64112 \\
\hline benzo[g,h,i]perylene & 64113 \\
\hline benzo[k]fluoranthene & 64114 \\
\hline chrysene & 64115 \\
\hline dibenz[a,h]anthracene & 64116 \\
\hline dibenzothiophene & 64117 \\
\hline indeno[1,2,3-cd]pyrene & 64118 \\
\hline pentachloroanisole $^{2}$ & 64119 \\
\hline perylene & 64120 \\
\hline phenanthridine & 64121 \\
\hline 2-fluorobiphenyl (surrogate) & 90754 \\
\hline nitrobenzene-d5 (surrogate) & 90755 \\
\hline terphenyl-d14 (surrogate) & 90756 \\
\hline \multicolumn{2}{|c|}{ Waste-indicator compounds by schedule 5433} \\
\hline 1,4-dichlorobenzene & 63163 \\
\hline 1-methylnaphthalene & 63165 \\
\hline polybrominated diphenyl ether $47^{2}$ & 63166 \\
\hline 2,6-dimethylnaphthalene ${ }^{2}$ & 63167 \\
\hline 2-methylnaphthalene & 63168 \\
\hline 3-beta-coprostanol ${ }^{2}$ & 63170 \\
\hline
\end{tabular}




\begin{tabular}{|c|c|}
\hline Parameter & Parameter code \\
\hline 3-methyl-1h-indole (skatol) & 63171 \\
\hline 3-tert-butyl-4-hydroxyanisole (bha) & 63172 \\
\hline 4-cumylphenol & 63173 \\
\hline 4-n-octylphenol & 63174 \\
\hline para-nonylphenol (total) & 63175 \\
\hline 4-tert-octylphenol & 63176 \\
\hline acetophenone & 63178 \\
\hline acetyl-hexamethyl-tetrahydronaphthalene (ahtn) & 63179 \\
\hline anthracene $^{2}$ & 63180 \\
\hline anthraquinone ${ }^{2}$ & 63181 \\
\hline atrazine & 63182 \\
\hline benzo[a]pyrene ${ }^{2}$ & 63183 \\
\hline benzophenone & 63184 \\
\hline beta-sitosterol & 63185 \\
\hline beta-stigmastanol & 63186 \\
\hline bis(2-ethylhexyl) phthalate ${ }^{2}$ & 63187 \\
\hline bisphenol a & 63188 \\
\hline bromacil & 63189 \\
\hline camphor & 63192 \\
\hline carbazole $^{2}$ & 63194 \\
\hline chlorpyrifos ${ }^{2}$ & 63195 \\
\hline cholesterol $^{2}$ & 63196 \\
\hline diazinon & 63198 \\
\hline nonylphenol, diethoxy- (total,np2eo) & 63200 \\
\hline 4-octylphenol diethoxylate-(op2eo) & 63201 \\
\hline diethyl phthalate ${ }^{2}$ & 63202 \\
\hline d-limonene & 63203 \\
\hline 4-octylphenol monoethoxylate-(op1eo) & 63206 \\
\hline fluoranthene $^{2}$ & 63208 \\
\hline hexahydrohexamethyl-cyclo-pentabenzopyran (hhcb) & 63209 \\
\hline indole & 63210 \\
\hline isoborneol & 63211 \\
\hline isophorone & 63212 \\
\hline isopropylbenzene (cumene) & 63213 \\
\hline isoquinoline & 63214 \\
\hline menthol & 63215 \\
\hline metolachlor & 63218 \\
\hline n,n-diethyl-meta-toluamide (deet) & 63219 \\
\hline naphthalene $^{2}$ & 63220 \\
\hline 4-nonylphenol monoethoxylate, total, (np1eo) & 63221 \\
\hline para-cresol & 63222 \\
\hline phenanthrene $^{2}$ & 63224 \\
\hline phenol & 63225 \\
\hline prometon & 63226 \\
\hline pyrene $^{2}$ & 63227 \\
\hline tri(2-butoxyethyl) phosphate & 63229 \\
\hline tri(2-chloroethyl) phosphate & 63230 \\
\hline tributyl phosphate & 63231 \\
\hline triclosan 2 & 63232 \\
\hline triphenyl phosphate & 63234 \\
\hline tris(dichloroisopropyl) phosphate & 63235 \\
\hline bisphenol a-d3 (surrogate) & 90735 \\
\hline decafluorobiphenyl (surrogate) & 90737 \\
\hline fluoranthene-d10 (surrogate) & 90738 \\
\hline
\end{tabular}




\begin{tabular}{|c|c|}
\hline Parameter & Parameter code \\
\hline \multicolumn{2}{|c|}{ Steroid hormones by schedule 6434} \\
\hline 17-beta-estradiol & 63164 \\
\hline 3-beta-coprostanol ${ }^{1}$ & 63170 \\
\hline bisphenol $\mathrm{a}^{1}$ & 63188 \\
\hline cholesterol $^{1}$ & 63196 \\
\hline equilenin & 63204 \\
\hline estrone & 63205 \\
\hline 17-alpha-ethynylestradiol & 63207 \\
\hline cis-androsterone & 63607 \\
\hline trans-diethylstilbestrol & 63620 \\
\hline mestranol & 63638 \\
\hline norethindrone & 63644 \\
\hline progesterone & 63657 \\
\hline 11-ketotestosterone & 64467 \\
\hline 17-alpha-estradiol & 64468 \\
\hline 4-androstene-3,17-dione & 64473 \\
\hline epitestosterone & 64477 \\
\hline equilin & 64479 \\
\hline estriol & 64480 \\
\hline dihydrotestosterone & 64484 \\
\hline testosterone & 64485 \\
\hline bisphenol a-d16 (surrogate) & 67310 \\
\hline progesterone-2,3,4-13c3 (surrogate) & 90512 \\
\hline cholesterol-d7 (surrogate) & 90772 \\
\hline estriol-2,4,16,17-d4 (surrogate) & 91617 \\
\hline 16-epiestriol-d2 (surrogate) & 91684 \\
\hline medroxyprogesterone-d3 (surrogate) & 91686 \\
\hline nandrolone-d3 (surrogate) & 91687 \\
\hline 17-b-estradiol-13c6 (surrogate) & 91757 \\
\hline estrone-13c6 (surrogate) & 91758 \\
\hline 17-alpha-ethynylestradiol-d4 (surrogate) & 91805 \\
\hline cis-androsterone-2,2,3,4,4-d5 (surrogate) & 91808 \\
\hline trans-diethylstilbestrol-d8 (surrogate) & 91809 \\
\hline mestranol-2,4,16,16-d4 (surrogate) & 91813 \\
\hline \multicolumn{2}{|c|}{ Organohalogens by lab code 8093} \\
\hline polybrominated diphenyl ether $47^{1}$ & 63166 \\
\hline triclosan $^{1}$ & 63232 \\
\hline endosulfan i & 63259 \\
\hline endosulfan ii, solids & 63260 \\
\hline benfluralin (benefin) & 63265 \\
\hline chlordane, cis & 63271 \\
\hline chlordane, trans & 63272 \\
\hline chlorpyrifos $^{1}$ & 63273 \\
\hline cyfluthrin & 63279 \\
\hline cyhalothrin & 63280 \\
\hline dcpa (dacthal) & 63282 \\
\hline dieldrin & 63289 \\
\hline endosulfan sulfate, solids & 63298 \\
\hline fipronil & 63313 \\
\hline fipronil sulfide & 63314 \\
\hline desulfinyl fipronil & 63316 \\
\hline nonachlor, cis & 63338 \\
\hline nonachlor, trans & 63339 \\
\hline oxyfluorfen & 63341 \\
\hline ddt, p,p' & 63345 \\
\hline
\end{tabular}




\begin{tabular}{ll}
\hline Parameter & Parameter code \\
\hline ddd, p,p' & 63346 \\
dde, p,p' & 63347 \\
pendimethalin & 63353 \\
tefluthrin & 63377 \\
trifluralin & 63390 \\
hexachlorobenzene ${ }^{1}$ & 63631 \\
triclosan, methyl- & 63639 \\
pentachloronitrobenzene & 63650 \\
tetradifon & 63665 \\
pentachloroanisole ${ }^{1}$ & 64119 \\
polychlorinated biphenyl 49 & 64725 \\
polychlorinated biphenyl 52 & 64726 \\
polychlorinated biphenyl 70 & 64727 \\
polychlorinated biphenyl 101 & 64729 \\
polychlorinated biphenyl 110 & 64730 \\
polychlorinated biphenyl 118 & 64731 \\
polychlorinated biphenyl 138 & 64732 \\
polychlorinated biphenyl 146 & 64733 \\
polychlorinated biphenyl 149 & 64734 \\
polychlorinated biphenyl 151 & 64735 \\
polychlorinated biphenyl 170 & 64736 \\
polychlorinated biphenyl 174 & 64737 \\
polychlorinated biphenyl 177 & 64738 \\
polychlorinated biphenyl 180 & 64739 \\
polychlorinated biphenyl 183 & 64740 \\
polychlorinated biphenyl 187 & 64741 \\
polychlorinated biphenyl 194 & 64742 \\
polychlorinated biphenyl 206 & 64743 \\
polybrominated diphenyl ether 66 & 64852 \\
polybrominated diphenyl ether 71 & 64853 \\
polybrominated diphenyl ether 85 & 64854 \\
polybrominated diphenyl ether 99 & 64855 \\
polybrominated diphenyl ether 100 & 64856 \\
polybrominated diphenyl ether 138 & 64857 \\
polybrominated diphenyl ether 153 & 64858 \\
polybrominated diphenyl ether 154 & 64859 \\
polybrominated diphenyl ether 183 & 64860 \\
oxychlordane & 64866 \\
pentabromotoluene & 64867 \\
1,2-bis(2,4,6-tribromophenoxy)ethane & 64868 \\
octachlorostyrene & 65217 \\
dechlorane plus & 65220 \\
pcb 202-13c12 (surrogate) & 90802 \\
dibromooctafluorobiphenyl (surrogate) & 91785 \\
p,p'-ddt-d8 (surrogate) & 91828 \\
\hline 'Anzed by med & \\
\hline
\end{tabular}

${ }^{1}$ Analyzed by two methods; results from this method are reported.

${ }^{2}$ Analyzed by two methods; results from this method are not reported. 
ISSN 2331-1258 (online)

https://doi.org/10.3133/ofr20171124 